Article

\title{
Product Design Evaluation Using Life Cycle Assessment and Design for Assembly: A Case Study of a Water Leakage Alarm
}

\author{
Tatbita Titin Suhariyanto ${ }^{1}$, Dzuraidah Abd Wahab ${ }^{1, *}$ (D) and Mohd Nizam Ab Rahman ${ }^{2}$ \\ 1 Centre for Integrated Design of Advanced Mechanical Systems (PRISMA), Faculty of Engineering and \\ Built Environment, Universiti Kebangsaan Malaysia, 43600 UKM Bangi, Selangor, Malaysia; \\ tatbita@siswa.ukm.edu.my \\ 2 Centre for Materials Engineering and Smart Manufacturing (MERCU), Faculty of Engineering and \\ Built Environment, Universiti Kebangsaan Malaysia, 43600 UKM Bangi, Selangor, Malaysia; \\ mnizam@ukm.edu.my \\ * Correspondence: dzuraidah@ukm.edu.my or drdzuwahab.ukm@gmail.com
}

Received: 19 June 2018; Accepted: 5 August 2018; Published: 9 August 2018

\begin{abstract}
This study proposed the use of an LCA supported by a design efficiency evaluation based on Design for Assembly principles to reduce the environmental impact of a product. To illustrate the methodology, a water leakage alarm (WLA) was selected as the object for a case study. Based on the identification and evaluation of the LCA results, it was inferred that the stage with the highest environmental impact was the manufacturing stage $(75.35 \%)$, followed by the use stage $(23.88 \%)$, the disposal of the WLA $(0.64 \%)$, and finally, the disposal of the batteries $(0.14 \%)$. For the manufacturing stage, the most interrelated categories were the hazardous waste and human toxicity, while the use stage was the main contributor to ozone depletion and acidification. Moreover, the disposal of the WLA and batteries contributed to the bulk waste. Furthermore, from the assembly evaluation, the design efficiency of the product was $14 \%$. Two recommendations for improving the design of the WLA were: (1) to reduce the number of screws from three units to one unit, and (2) to eliminate the use of a cable and to replace it with a wireless component. By implementing both the proposed recommendations, the design efficiency was improved by as much as $34 \%$. From the environmental perspective, there is not much difference between the wired alarm and wireless alarm. The wired alarm was considered to be more environmentally friendly in terms of product manufacturing but the wireless alarm has an advantage in terms of design and energy efficiency. By combining LCA and DFA design evaluation, a more comprehensive perspective of the product life cycle can be achieved.
\end{abstract}

Keywords: life cycle assessment; design for assembly; design efficiency; sustainable strategy

\section{Introduction}

Sustainability, which is regarded as a universal challenge for industrial sectors, calls for comprehensive action towards the employment of sustainable strategies [1]. These strategies are aimed at enhancing the environmental, economic, and social factors of business processes and products to support stakeholders in making the right choices and best decisions [2]. They promise an increase in both tangible and intangible benefits to firms due to several reasons: acceleration in the time taken for the products to reach the market, reduction of regulatory constraints, increase in consumer demands, decrease in manufacturing costs and liabilities, improvements in employee health and safety, and increase in the value-added delivery of the products to consumers [3]. 
However, many manufacturers are not concerned with the sustainability aspect of their products, especially the increasing environmental impacts brought about by industrial activities. As much as $75 \%$ of the material resources used in products and their manufacturing processes are disposed in the environment as waste within a year [4]. Furthermore, the development of industrial activities has contributed to an increase in global greenhouse gas (GHG) emissions. According to Reference [5], 65\% of GHG emissions are caused by industrial processes and the use of fossil fuels. Moreover, the quantity of generated e-waste globally was around 41.8 million tonnes in 2014 [6]. This figure will continue to rise along with human productivity and technological innovations. Based on Reference [7], up to $90 \%$ of the world's e-waste is illegally traded or dumped each year.

The above conditions must first be addressed by evaluating the environmental performance of products. To date, a systematic assessment tool which has the potential to deal with the problem is the Life Cycle Assessment (LCA). The LCA is a quantitative approach to evaluate the environmental impacts of products based on international standards, i.e., the International Standards Organisation (ISO) [8]. It has been adopted by a number of corporations and non-profit organisations as a support tool to achieve several purposes, such as strategic planning, product design improvement, and marketing $[8,9]$.

The LCA is a useful tool for the promotion of environmentally-conscious products. It has been studied and implemented extensively by many researchers [10-14]. From the LCA results, many stakeholders will be able to identify opportunities for improvements and to determine the appropriate sustainable strategies. The LCA emphasises environmental impacts assessments which occur at all stages of the life cycle of a product, as shown in Figure 1.

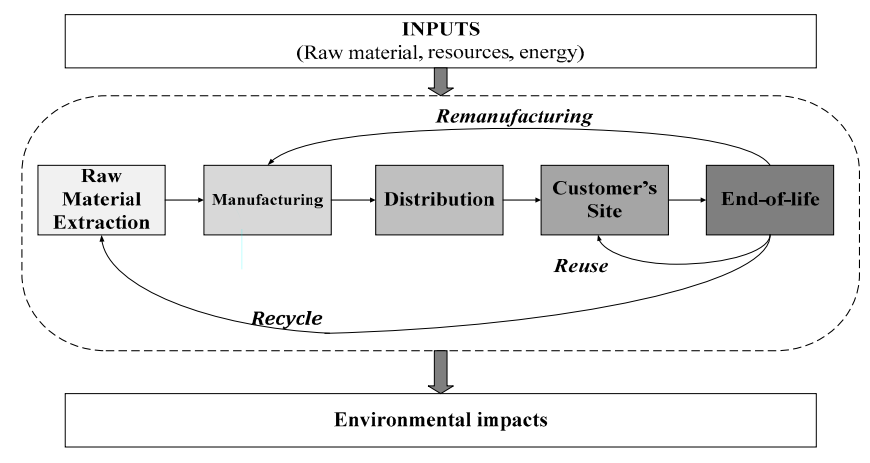

Figure 1. Product Life Cycle.

When it comes to sustainability, how a product ends its life is just as critical as how it is produced from the extraction of the raw materials, the manufacturing process, the distribution, and finally, its use. Therefore, the concept of 6Rs (Reduce, Reuse, Recycle, Recover, Redesign, and Remanufacture) was introduced to minimise the environmental burden of a product in the whole life cycle [4]. This concept can be implemented in the early design stage, and it improves the product design, changing it from a "cradle-to-grave" to a "cradle-to-cradle" design. Its aim is to support a sustainable product design which is focused on post-use treatments.

Unfortunately, the LCA methodology still neglects the aspect of product design and development (PDD). Although PDD has an important role in maintaining the sustainable development of a product as a whole $[15,16]$, the application of the LCA to PDD has not been critically addressed, and has been given little consideration in LCA researches $[17,18]$. Therefore, this paper proposed the use of LCA supported by a design efficiency evaluation to reduce the overall environmental impacts of a product. This concept is generally referred to as "eco-design". Integrating eco-design into PDD offers several benefits to the industry and public organisations such as economic benefits, legislation fulfilment, public image improvement, and employee motivation enhancement [19]. Eco-design must be integrated into the strategic planning and operational management to gain these advantages [19]. 
The aim of this paper was to deploy the "redesign" concept based on the results of the LCA. Redesign refers to activities that are aimed at simplifying the existing design of a product to facilitate future post-use activities [4]. Up to now, the application of the LCA results has been generally limited to improving a particular stage of a product, and the results have yet to be used to establish a more environmentally-conscious design.

In this study, a design efficiency evaluation was conducted based on the Design for Assembly (DFA) method which can also be called an assembly efficiency method [20]. This method effectively analyses the ease of assembly and disassembly, identifies assembly problem areas, and recommends some alternative designs for simplifying the product structure. In the long term, the implementation of the DFA method can contribute to a reduction in manufacturing and assembly costs. When a product can be assembled and disassembled easily, the chances for it to be reused or recycled will increase, and further reductions in environmental impacts can be achieved.

In the rest of the paper, Section 2 presents the literature review regarding the use of the life cycle technique and the principles for designing a product. Section 3 explains the materials and methodology used in this study. To illustrate the methodology, a water leakage alarm (WLA) was selected as the object for a case study, which is extensively discussed in Sections 4 and 5 . Section 4 explains the results of LCA study of the product, while Section 5 presents the discussion of life cycle interpretation and design efficiency evaluation. Lastly, Section 6 summarises the conclusions and contributions of the study, as well as recommendations for further researches.

\section{Literature Review}

The use of the life cycle technique to support PDD has attracted many researchers. In recent years, many studies have been undertaken to realise that objective [21-27]. Case studies have been chosen by some researchers to present the chances for obtaining the first insight with detailed understanding into a particular field [28]. Each case study contributes to a specific knowledge and practice. The selected object for a case study is considered to be able to illustrate the proposed methodology, and is also related to the problem of interest. For example, some researchers select electronic products as the objects for their case study in order to focus on improving the use and design of a product. On the other hand, when the problem of interest is focused on material and EOL design, some researchers tend to select polymer-based products.

As summarised in Table 1, the review highlighted the main points which are important in developing a product design by incorporating it within the life cycle technique. Some researchers often use the life cycle technique and design principles separately. The Design for Disassembly (DFD), Design for Modularity (DFM), Design for Recycle (DFR), and Design for Environment (DFE) are among several methods that are often used to evaluate product designs. However, these approaches are still considered to be less satisfactory because a specific design principle usually only focuses on a specific problem. On the other hand, some researchers particularly use the life cycle technique to evaluate the environmental impacts of the products. The most commonly used life cycle technique is the LCA. This technique can help designers to analyse potential improvements to minimise the environmental impacts of products, establish new product designs, and compare a number of products $[29,30]$. However, this technique only focuses on the environmental aspects, while neglecting the others.

To overcome the limitations of the LCA, some researchers extended the conventional LCA. For example, the Life Cycle Reliability Assessment (LCRA) is a Bayesian model updating approach, which includes a reliability assessment for the development of new products [31]. Also, the Life Cycle Design Assessment (LCDA) is an approach to product assessment that deals with technological changes and increasing volume using an axiomatic design theory [32]. The Life Cycle Simulation (LCS) is also a method that was proposed to minimise environmental loads and resource consumption through simulation modelling [33]. Even though these techniques are more advanced than the conventional LCA, researchers may face difficulties with the product architecture when it comes to improving the product design. To deal with that problem, some researchers have combined other life cycle techniques with 
some design principles. By integrating a specific life cycle technique and design principle, they have been able to develop a new product design with lower negative impacts across the life cycle.

Some researchers often use the LCA accompanied by the DFE. In practical terms, the DFE, coupled with a reasonable use of the LCA, is an effective tool for achieving a sustainable product design [34]. Moreover, the DFE is also often paired with other life cycle techniques, such as the life cycle planning (LCP), life cycle design (LCD), and life cycle engineering (LCE) methods. Unlike the LCA, the LCP considers the whole life cycle of a product and fulfils customer satisfaction by establishing an eco-design product. The LCP, which is supported by a Quality Function Deployment (QFD) for the generation of customer requirements and an LCPlanner software to assess the environmental impacts [35], is presented as a new approach for multigenerational product planning [36]. Even though this method presents a comprehensive design concept, the software is difficult to access and the methodology has a limited environmental assessment. In addition, the Life Cycle Modelling for Design (LCMD) was also introduced by combining the LCA with a probabilistic design method to cope with the complexity of a product and various design options [37]. Later on, a method which focused on a modular design and geometric modelling to differentiate the life cycle options was proposed by Umeda et al. [25]. Furthermore, some researchers included other supporting methods to enhance their methodologies, such as the combination of the Fuzzy Analytic Hierarchy Process (FAHP) method and the LCD to evaluate product maintainability based on the product life cycle [22] and the introduction of the Knowledge-based Approximate Life Cycle Assessment System (KALCAS) to improve environmental efficiency using artificial neural networks [23]. However, the integration of specific methods is relatively complex and difficult to implement in other problems.

Since both the DFE and LCA are focused on the environmental aspect of a product, this integration method lacks the ability to capture other aspects of a product, such as operation time, cost and quality. To fill the gap in previous studies, this paper proposed a combination of the LCA technique with the DFA to improve the design of a product. This was also due to a few studies that combined the LCA and DFA to support the PDD. These methods of incorporation are expected to evaluate both the life cycle and design efficiency aspects.

Disassembly and reassembly are the most critical factors for improving the efficiency of the reuse or remanufacturing of products [38]. The time taken for the disassembly process should be minimised using DFD guidelines, while the reassembly should refer to DFA guidelines. Mostly, a product which is designed to be easily assembled can also be easily disassembled [39]. Kaebernick and Kara [40] stated that the technical and economic problems of production can be reduced significantly if a product is properly designed for assembly and disassembly. DFA and DFD studies were conducted by several researchers such as Bevilacqua et al. [9], Bogue [41], Bras [42], Go et al. [43], and Kaebernick and Kara [40]. Bevilacqua et al. [9] discussed the Hitachi Group Eco-design Management Guidelines, which identified the environmental attributes of these requirements, such as energy efficiency, ease of disassembly and disposal, and the effects of these attributes. Bogue [41] highlighted the importance of the DFD concept and identified the key DFD principles. Bras [42] provided an overview of an industry, including a typical facility-level process, and discussed the qualitative design for remanufacturing guidelines, which also included the DFA and DFD. Go et al. [43] presented a review of several disassembly methods and concluded that there was a need for an effective disassembly method in order to enhance the recovery of the products. Finally, Kaebernick and Kara [40] discussed several disassembly processes in recycling and reusing technologies to reduce the production of new materials by bringing in used materials.

In summary, Otto and Wood [39] divided the DFA guidelines into several categories: system design guidelines that reduce assembly, ease of handling of the required parts, ease of insertion of the parts during assembly, and ease of the actual attachment and joining methods. In this study, the implementation of these guidelines were enriched by the application of the DFA guidelines by Boothroyd et al. [20]. The experiment on the DFA guidelines will be discussed in detail in Section 5. 
Table 1. Related Literature Review in Life Cycle Assessment and Product Design.

\begin{tabular}{|c|c|c|c|c|c|c|c|}
\hline Author & Case-Study Object & Problem of Interest & Objective & Life Cycle Technique & Design Principles & Supporting Method & Supporting Software \\
\hline Fitch and Cooper [37] & Automotive car & $\begin{array}{c}\text { Material; } \\
\text { manufacturing }\end{array}$ & Present LCMD methodology & LCMD & $\begin{array}{c}\text { Probabilistic } \\
\text { design methods }\end{array}$ & - & - \\
\hline Kobayashi [35] & Personal computers & $\begin{array}{c}\text { Quality; cost; } \\
\text { environmental aspect }\end{array}$ & $\begin{array}{l}\text { Present LCP methodology and } \\
\text { software tool }\end{array}$ & LCP & DFE & QFD & LCPlanner software \\
\hline Park and Seo [23] & Refrigerator & $\begin{array}{l}\text { Cost and design } \\
\text { efficiency }\end{array}$ & $\begin{array}{c}\text { Assess the environmental impacts } \\
\text { using KALCAS }\end{array}$ & LCA & DFE & KALCAS & - \\
\hline Sakao [24] & Hair dryer & Product design; use & $\begin{array}{l}\text { Propose a general design } \\
\text { methodology to support } \\
\text { environmentally conscious design }\end{array}$ & LCA & DFE & QFDE; TRIZ & - \\
\hline Umeda et al. [25] & Printer & Product design & $\begin{array}{l}\text { Propose a method for determining } \\
\text { modular structure }\end{array}$ & LCD & DFM & - & - \\
\hline Tchertchian et al. [44] & Espresso machines & Cost; design; use & $\begin{array}{l}\text { Propose green design of reusable } \\
\text { modules with environmental and } \\
\text { economic evaluations }\end{array}$ & LCA & DFM & - & - \\
\hline Peng et al. [31] & $\begin{array}{l}\text { Gantry machining } \\
\text { centre }\end{array}$ & Product reliability & $\begin{array}{l}\text { Present a BMUA for life cycle } \\
\text { reliability assessment }\end{array}$ & LCRA & - & BMUA & - \\
\hline Kim et al. [32] & Battery technologies & $\begin{array}{c}\text { Economic and } \\
\text { environmental aspects }\end{array}$ & $\begin{array}{l}\text { Propose a new approach to product } \\
\text { assessment for technology changes } \\
\text { and increasing volume }\end{array}$ & LCDA & - & $\begin{array}{l}\text { Axiomatic design } \\
\text { theory }\end{array}$ & - \\
\hline Fitzpatrick et al. [21] & $\begin{array}{l}\text { Integrated desktop } \\
\text { personal computer }\end{array}$ & $\begin{array}{l}\text { Material; use; service; } \\
\text { EOL }\end{array}$ & $\begin{array}{l}\text { Describe the LCE of an integrated } \\
\text { desktop computer system from the } \\
\text { perspective of an SME }\end{array}$ & LCE & DFE; DFD & - & - \\
\hline Souza and Borsato [45] & Automobile seat & EOL & $\begin{array}{l}\text { Develop an assessment tool based on } \\
\text { three methods to be used by } \\
\text { enterprises, with three increasing } \\
\text { sustainability levels to be selected }\end{array}$ & LCA & DFE & $\begin{array}{c}\text { Stage-Gate model; } \\
\text { Toyota's set-based } \\
\text { approach; sustainable } \\
\text { principles } \\
\end{array}$ & SimaPro \\
\hline Matsuyama et al. [33] & Smartphone & Material; service; EOL & $\begin{array}{l}\text { Propose a method for modelling both } \\
\text { nominal information of a product life } \\
\text { cycle and the entity information }\end{array}$ & LCD; LCS & - & $\mathrm{CAD}$ & - \\
\hline
\end{tabular}


Table 1. Cont.

\begin{tabular}{|c|c|c|c|c|c|c|c|}
\hline Author & Case-Study Object & Problem of Interest & Objective & Life Cycle Technique & Design Principles & Supporting Method & Supporting Software \\
\hline Jian et al. [22] & Loader's transmission & All life cycle stages & $\begin{array}{c}\text { Propose a concept and connotation of } \\
\text { product maintainability combined } \\
\text { with actual demand }\end{array}$ & LCD & DFLC & FAHP & - \\
\hline Lacasa et al. [46] & $\begin{array}{l}\text { Solar tracker; } \\
\text { isothermal container }\end{array}$ & $\begin{array}{l}\text { All life cycle stages; } \\
\text { Economic and social } \\
\text { aspects }\end{array}$ & $\begin{array}{l}\text { Propose a product development } \\
\text { methodology that includes } \\
\text { traditional design criteria }\end{array}$ & LCA & DFE & Engineering metrics & - \\
\hline
\end{tabular}

Note: BMUA (Bayesian Model Updating Approach); CAD (Computer Aided Design); DFD (Design for Disassembly); DFLC (Design for Life Cycle); DFM (Design for Modularity); DFE (Design for Environment); DFR (Design for Recycle); FAHP (Fuzzy Analytic Hierarchy Process); KALCAS (Knowledge-based Approximate Life Cycle Assessment System); LCA (Life Cycle Assessment); LCD (Life Cycle Design); LCDA (Life Cycle Design Assessment); LCE (Life Cycle Engineering); LCMD (Life Cycle Modelling for Design); LCP (Life Cycle Planning); LCRA (Life Cycle Reliability Assessment); LCS (Life Cycle Simulation); QFD (Quality Function Deployment); QFDE (Quality Function Deployment for Environment); SME (Small Medium Enterprises) TRIZ (Theory of Inventive Problem Solving). 


\section{Materials and Methods}

This research consists of three important phases. Each phase indicates the use of different methods or techniques which results in different outputs (see Figure 2). Before conducting the LCA study, the first step was to identify the product system and the performance measurement. Data were collected from primary and secondary sources namely observation and literature, which includes material and energy consumption, the used process technology, and the product specification. Once data input was completed, the potential environmental impacts of the existing product were assessed according to the LCA framework.

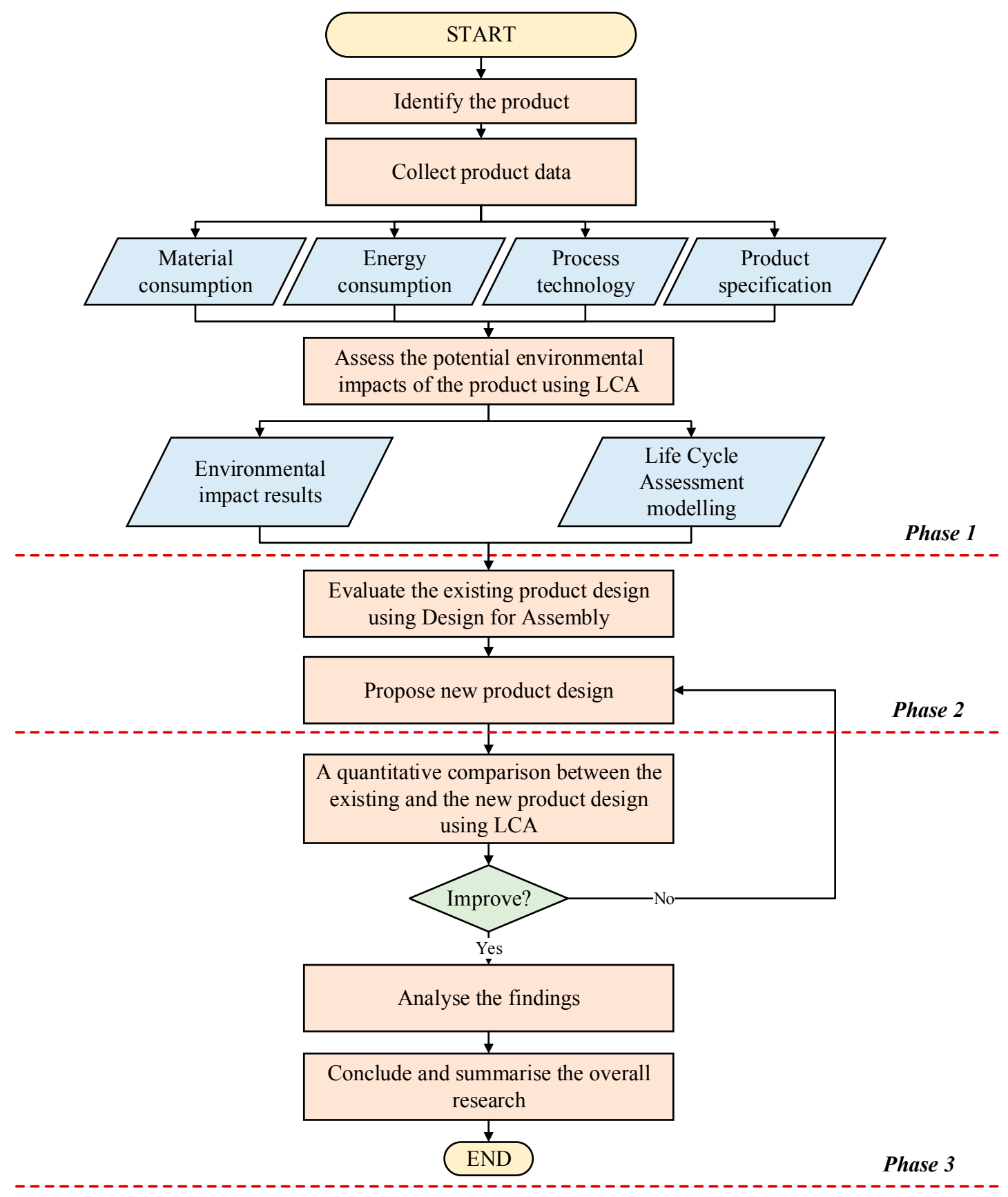

Figure 2. Research Methodology.

As shown in Figure 3, the LCA methodology consists of four steps, namely the definition of the goal and scope, inventory analysis or life cycle inventory (LCI), life cycle impact assessment 
(LCIA), and life cycle interpretation. In the goal and scope definition, the purpose and method of an LCA are defined clearly and unambiguously. It also provides an obvious description of the product system which consists of system boundaries and functional unit. The second step is LCI, which is the process of identifying and quantifying energy consumption and released emissions during the entire life cycle of a product. This phase compiles several data; such as the amount of energy, the consumption of material, and the quantity of emissions. The third step namely LCIA, is aimed at evaluating the environmental impacts of products based on LCI results within the given project scope and to determine the relative importance of each elementary flow within a given environmental problem. Finally, the last phase of LCA consists of the summary of LCI analysis and LCIA as a basis for conclusions, recommendations, and decision making in compliance with the goal and scope definition. This study used SimaPro Ph.D. version as the software to build the LCA model and to generate the results of the environmental impacts.

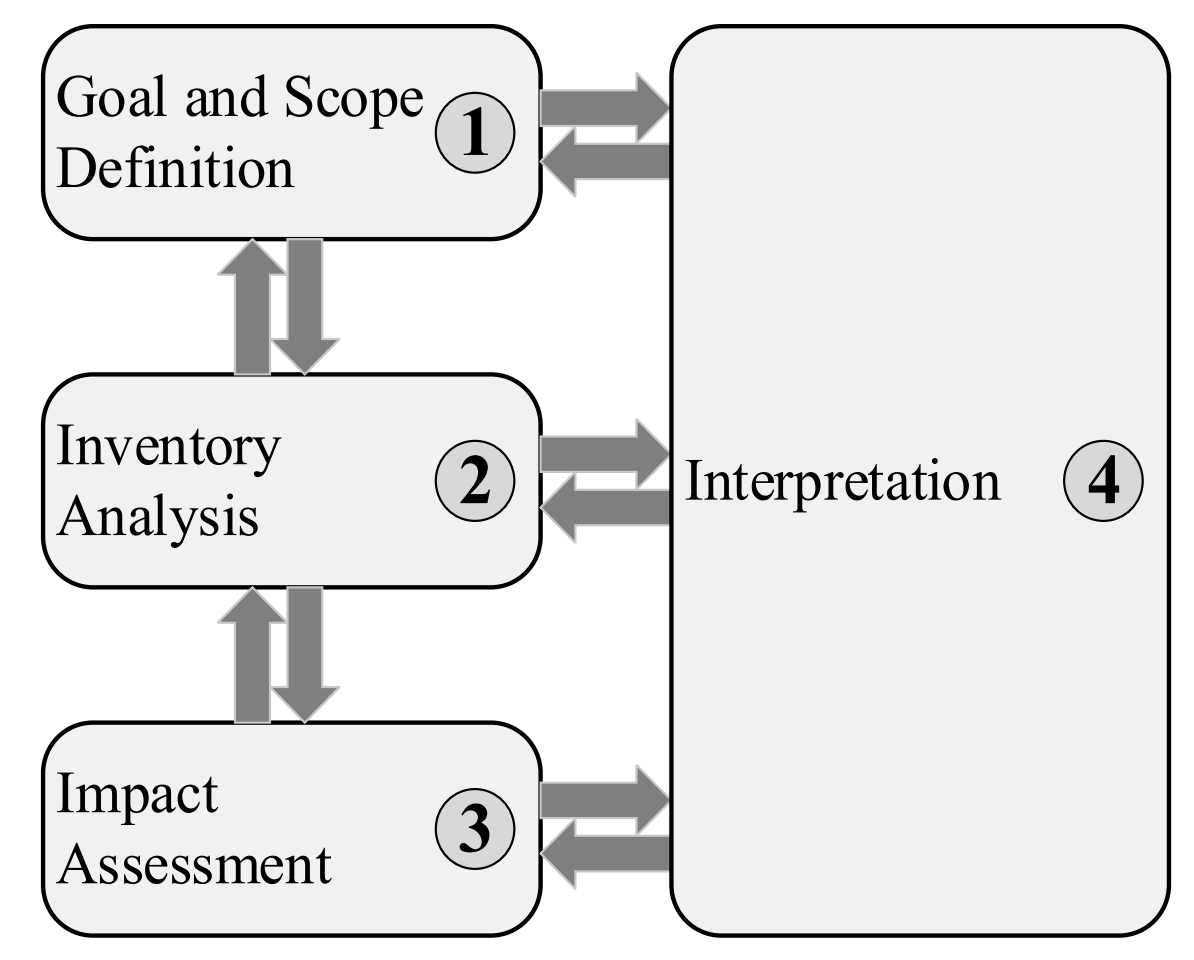

Figure 3. The LCA Framework.

The second phase was to evaluate the design efficiency based on the DFA method. Since LCA only focuses on the environmental impacts of the product, this methodology usually neglects the design aspects of the product. Therefore, LCA and DFA were combined to assess both the aspects of environmental performance and product design. In redesigning the product, the guidelines from Boothroyd et al. [20] were applied in order to establish a more environmentally-conscious product. Moreover, by implementing DFA, the cost and operation time of the new product design were expected to be reduced.

Finally, in the third phase, the existing design was compared to the new design quantitatively using LCA. From this phase, the environmental impacts of both designs can be compared and analysed to understand which design is more environmentally friendly. By combining LCA and design evaluation, a more comprehensive perspective of the product life cycle can be achieved so as to promote a sustainable product design.

The materials of the case example used in this study were identified based on a direct observation of the product in order to determine the used product materials and the processes involved, which are explained in detail in Section 4.2. The LCA modelling process was performed using SimaPro software 
Ph.D. version which is integrated with the Ecoinvent database. This database contains all the inputs for making a product or service [47].

To illustrate the methodology, an electronic safety product, specifically a water leakage alarm (WLA), was chosen as the object for a case study (see Figure 4). It consists of two main parts: an alarm and a sensor. This product functions as a detector of water leakage in bathrooms or water reservoirs. When a leak occurs, it will be detected by the sensor, which will alert the user through its sound. The alarm was selected for this study because it is frequently used in homes or public places (e.g., hotels, hospitals, etc.), and consumes electricity during its use-phase.
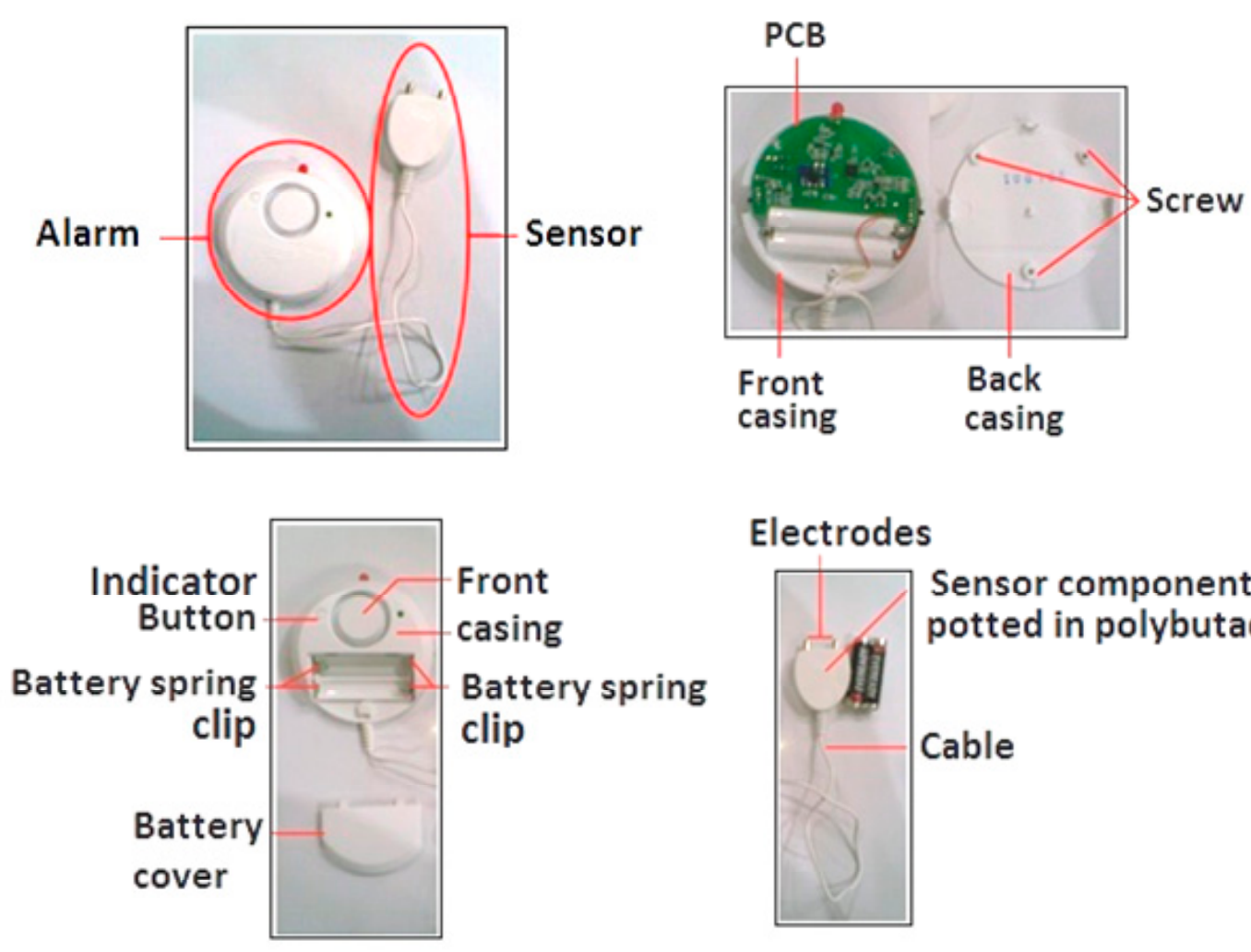

\section{Electrodes}

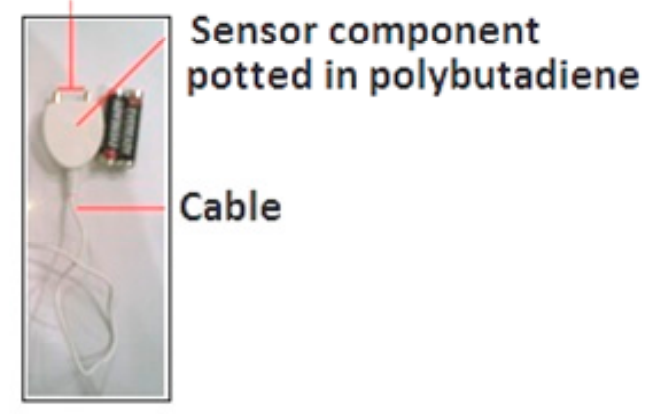

Figure 4. WLA disassembly.

In this paper, the results of LCA are presented in Section 4. Next, the DFA methodology and design improvements are discussed in detail in Section 5. In Section 6, several recommendations are proposed to improve the product design and to discuss the comparison between the existing product design product and the proposed new design. At the end of the paper, a general conclusion from the study and recommendations for future work are proposed.

\section{Results of Life Cycle Assessment}

In the next subsection, each stage of the LCA will be discussed in detail.

\subsection{Goal and Scope Definition}

The goal of this study was to evaluate the environmental performance and identify the critical point in the life cycle of the WLA. The next step was to determine the scope, which consisted of the functional unit (FU), reference flow (RF), and the product system [8,29]. The FU must contain three aspects: the magnitude of the product, the duration of the product, and the intended quality [48]. Therefore, the FU in this study was defined as the prevention of water leaks for 3 years. The RF, which fulfilled the FU, was a water leakage alarm. 
The product system, also known as the system boundary, had three primary stages as follows: manufacturing, use, and EOL, as shown in Figure 5. The manufacturing stage, as shown in Figure 6, consists of wire drawing, injection moulding, metal working, conventional drilling, surface mount technology, and electronic components production. However, the packaging process was excluded from the system boundary. At the use phase, it was assumed that the product could be used for 3 years. The product used two rechargeable AAA batteries, which needed to be replaced every 6 months. Therefore, the use and disposal of batteries were included in the system boundary, while the production of batteries was excluded. For the EOL stage, the product and the batteries were assumed to be disposed of in a landfill without any further treatment. This assumption was based on existing literature that claimed many electronic products were often wasted after the use stage [44,49].

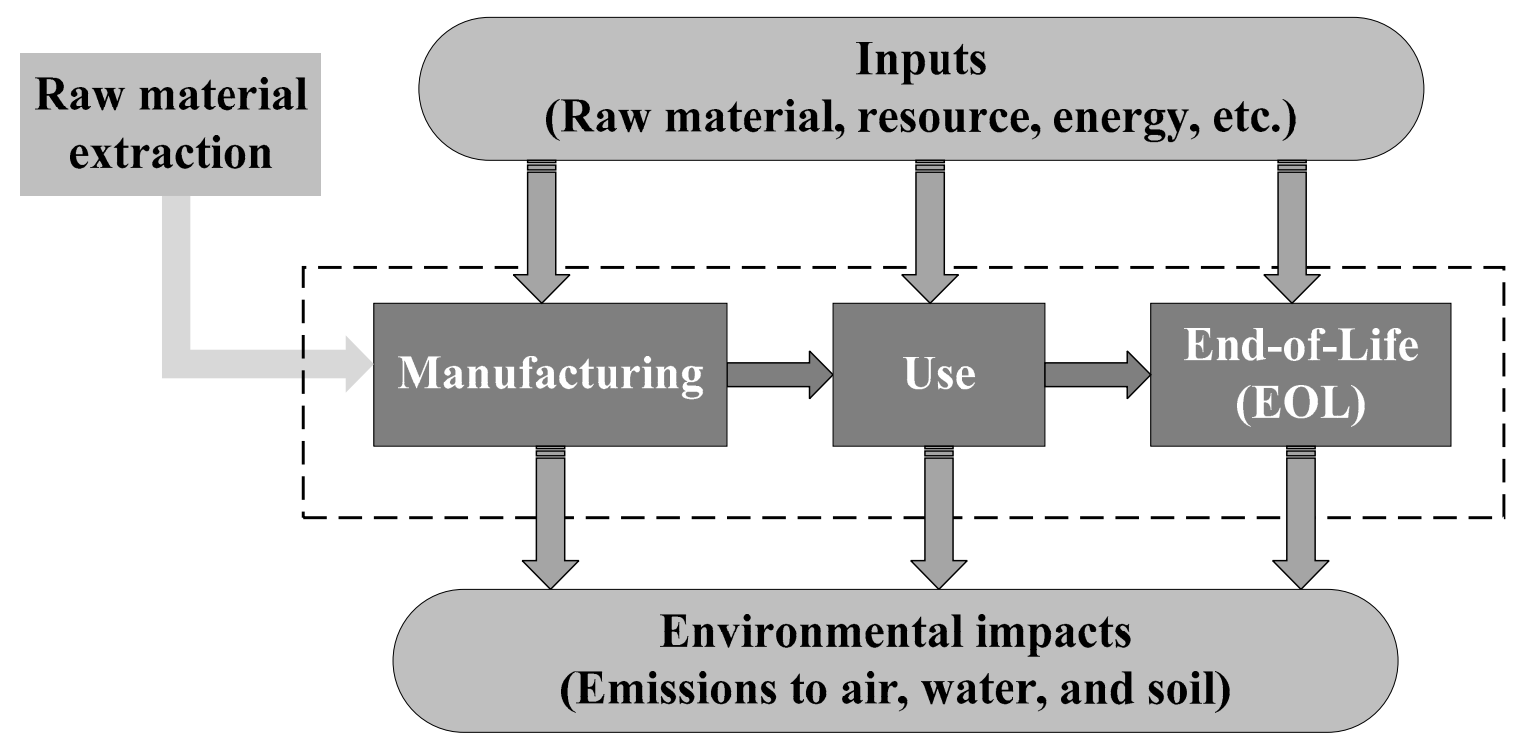

Figure 5. Product system of WLA. 


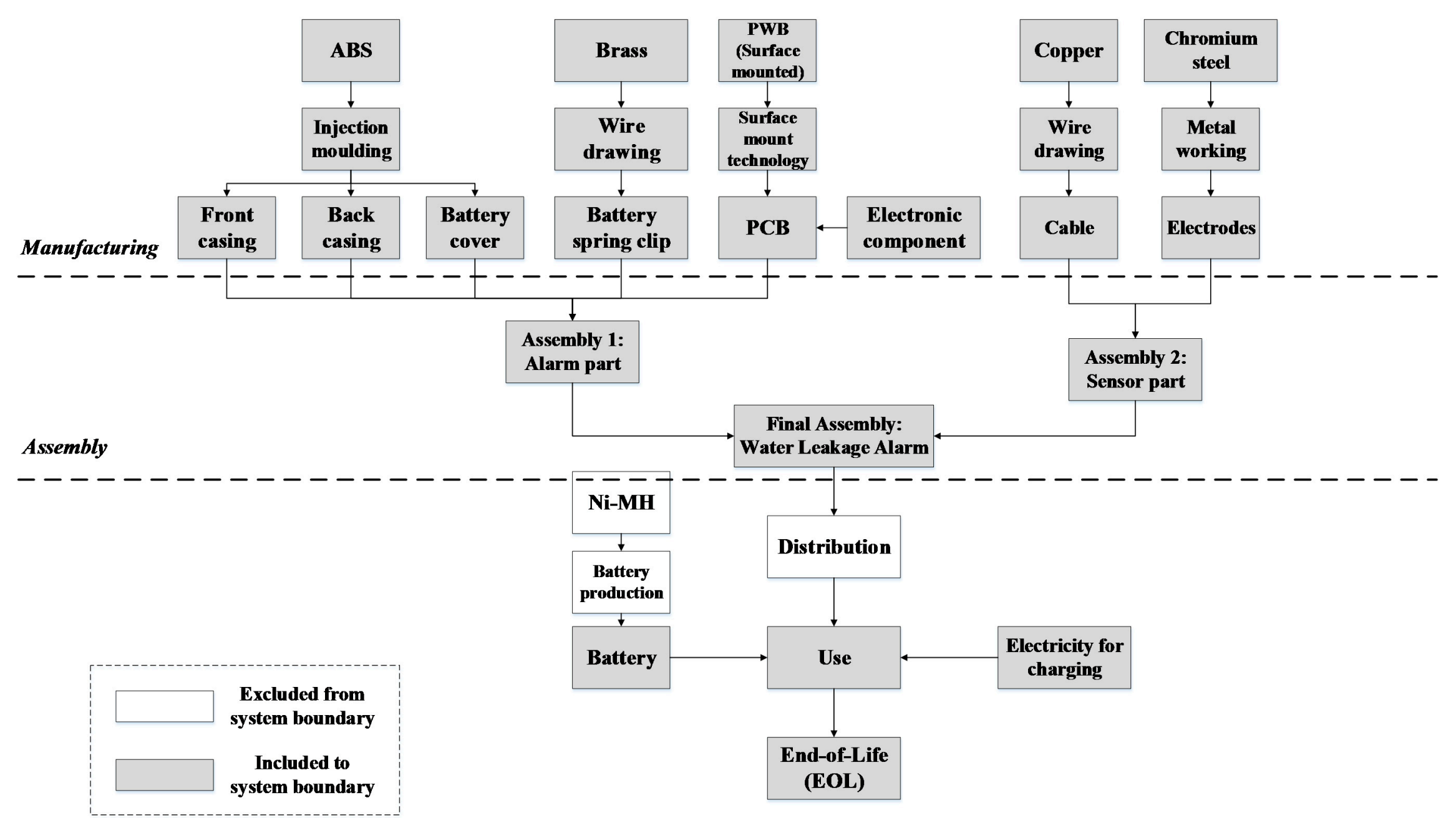

Figure 6. WLA manufacturing process. 
Some stages were discarded from the system boundary because of a lack of available data. The raw material stage involved ambiguous data because the materials had been imported from several places that were difficult to trace. Another eliminated stage was the distribution stage. This stage had uncertainties since the product had been delivered to different countries from the manufacturer. However, it did not have a significant influence on the outcome of the LCA because the main stages of the product were still included and evaluated.

\subsection{Life Cycle Inventory}

Table 2 provides the LCI datasets for the manufacturing stage. This table was compiled based on the type of material, the amount, and the process step for each part. Also, the detail of the electronic components can be seen in Table 3. It was assumed that these parts and components were assembled manually using a standard assembly tool kit.

Table 2. LCI of the manufacturing stage.

\begin{tabular}{cccc}
\hline Name of Part & Type of Material & Amount (g) & Process Step \\
\hline Battery spring clip & Brass & 3.3 & Wire drawing \\
\hline Cable & Copper & 2 & Wire drawing \\
\hline $\begin{array}{c}\text { Front and back casing (include indicator } \\
\text { button, battery and siren cover) }\end{array}$ & $\begin{array}{c}\text { Acrylonitrile butadiene } \\
\text { styrene (ABS) }\end{array}$ & 27.5 & Injection moulding \\
\hline Electrode & Chromium steel & 3.4 & Metal working \\
\hline Potting material for sensor component & Polybutadiene & 17.5 & Injection moulding \\
\hline Screw & Chromium steel & 0.5 & Conventional drilling \\
\hline Electronic components & Varies & 30.67 & Varies \\
\hline
\end{tabular}

Table 3. List of electronic components.

\begin{tabular}{cc}
\hline Name of Components & Amount $(\mathrm{g})$ \\
\hline General purpose NPN transistor & 0.2 \\
50 K trimpot & 28 \\
47 ohm resistor & 0.57 \\
Light emitting diode & 0.5 \\
Switch button & 0.7 \\
Siren & 0.7 \\
PCB & 28.3 \\
\hline
\end{tabular}

Furthermore, during the use stage, the WLA was assumed to be frequently used or rang. There are two usage scenarios by using non-rechargeable and rechargeable batteries. Table 4 presents the equivalent comparison between the two types of battery. For the non-rechargeable battery, it was assumed that the product requires 4 batteries per year with two times replacement every year, thus there are 12 batteries in total. For the rechargeable battery, it was assumed that the product only requires 2 batteries for 3 years but the batteries need to be recharged twice a year. Although, non-rechargeable batteries are more suitable for low-drain products such as a water alarm, this study selected the rechargeable battery as the energy source since the researcher has limited access to the SimaPro database. The LCI of the use stage can be seen in Table 5 by detailing each required input. Since the product and batteries were assumed to be disposed of in a landfill, no inputs were needed for the EOL stage. 
Table 4. Usage scenario.

\begin{tabular}{ccc}
\hline Type of Battery & Non-Rechargeable Battery & Rechargeable Battery \\
\hline Usage scenario & $\begin{array}{c}\text { 4 batteries per years with two } \\
\text { times replacement every year }\end{array}$ & $\begin{array}{c}\text { 2 batteries with 2 recharging times } \\
\text { per battery per year }\end{array}$ \\
\hline Total life time & 3 years & 3 years \\
\hline Total required battery & 12 batteries & 2 batteries \\
\hline Total electricity for recharging & - & 115.2 watt hour \\
\hline
\end{tabular}

Table 5. LCI of the use stage.

\begin{tabular}{cc}
\hline Input & Amount \\
\hline $\begin{array}{c}\text { Rechargeable AAA Ni-MH battery } \\
\text { Electricity }\end{array}$ & 2 units (3-year lifetime) \\
& $115.2 \mathrm{~W} \mathrm{~h} \mathrm{(6} \mathrm{recharging} \mathrm{time} \mathrm{per} \mathrm{battery)}$ \\
\hline
\end{tabular}

\subsection{Life Cycle Impact Assessment}

The main innovations in the EDIP2003, the updated Danish LCA methodology of the EDIP97, include the exposure to characterisation modelling [50]. This LCIA method has been recommended for use as an alternative to the EDIP97 for performing site-generic characterisations [51]. Table 6 represents 18 different impact categories which are classified into nine main categories used in this study [50,51]. Since there is no Malaysian LCIA method available as yet, this method was assumed to be the most appropriate method for use in this study. The results of the LCIA based on the EDIP2003 can be seen in Table 7. This table presents the potential impacts of the WLA based on each impact category. It is difficult to interpret the results as they are given in different units. Therefore, Figure 7 shows the normalised potential environmental impacts of the product, while Table 8 provides the environmental profile per life cycle stage.

Table 6. Description of each impact category based on EDIP2003.

\begin{tabular}{|c|c|}
\hline Impact Category & Description \\
\hline Global warming & $\begin{array}{l}\text { The increasing natural greenhouse effect over the past few centuries by } \\
\text { human activities which leads to accumulation of such gases as } \mathrm{CO}_{2}, \mathrm{~N}_{2} \mathrm{O} \text {, } \\
\mathrm{CH}_{4} \text { and halocarbons in the atmosphere. }\end{array}$ \\
\hline Ozone depletion & $\begin{array}{l}\text { The stratospheric content of ozone is disturbed as a consequence of } \\
\text { manmade emissions of halocarbons, i.e., CFCs, HCFCs, halons and other } \\
\text { long-lived gases containing chlorine and bromine. }\end{array}$ \\
\hline Photochemical Ozone formation & $\begin{array}{l}\text { Nitrogen oxides }\left(\mathrm{NO}_{\mathrm{x}}\right) \text { and volatile organic compounds }(\mathrm{VOCs}) \text { react to } \\
\text { form ozone which initiated by sunlight. }\end{array}$ \\
\hline Acidification & $\begin{array}{l}\text { A regional effect that is caused by releases of protons in the terrestrial or } \\
\text { aquatic ecosystems. }\end{array}$ \\
\hline Terrestrial eutrophication & $\begin{array}{l}\text { Availability of nutrients in excess of the optimum load which leads to a } \\
\text { change of the species composition and to an unwanted change in the } \\
\text { character of the given ecosystem. }\end{array}$ \\
\hline Aquatic eutrophication & The process of becoming rich of nutrients in the aquatic ecosystems. \\
\hline Human toxicity air & $\begin{array}{l}\text { The exposure of humans to environmental pollutants through inhalation } \\
\text { with air and ingestion with food and water (and sometimes also soil). }\end{array}$ \\
\hline Eco-toxicity & $\begin{array}{l}\text { Chemical emissions which affect the function and structure of the } \\
\text { ecosystems through toxic effects on the organisms living in them. }\end{array}$ \\
\hline Waste streams & $\begin{array}{l}\text { Waste streams are divided in four categories, bulk waste (not hazardous), } \\
\text { hazardous waste, radioactive waste and slags and ashes which are } \\
\text { reported on a mass basis. }\end{array}$ \\
\hline
\end{tabular}


Table 7. Results of Environmental Impacts of WLA.

\begin{tabular}{|c|c|c|c|c|c|c|c|}
\hline Impact Category & & Unit & Manufacturing & Use & $\begin{array}{c}\text { Disposal of } \\
\text { Product }\end{array}$ & $\begin{array}{c}\text { Disposal of } \\
\text { Battery }\end{array}$ & Total \\
\hline Global warming 100a & GW & $\mathrm{kg} \mathrm{CO} 2 \mathrm{eq}$ & $3.56 \times 10^{0}$ & $4.14 \times 10^{0}$ & $3.56 \times 10^{-2}$ & $7.62 \times 10^{-3}$ & $7.74 \times 10^{0}$ \\
\hline Ozone depletion & OD & $\mathrm{kg}$ CFC11 eq & $3.62 \times 10^{-7}$ & $1.75 \times 10^{-5}$ & $2.38 \times 10^{-10}$ & $4.94 \times 10^{-11}$ & $1.79 \times 10^{-5}$ \\
\hline Ozone formation (Vegetation) & OFV & $\mathrm{m}^{2} \cdot \mathrm{ppm} \cdot \mathrm{h}$ & $3.06 \times 10^{1}$ & $2.53 \times 10^{1}$ & $5.60 \times 10^{-1}$ & $1.20 \times 10^{-1}$ & $5.66 \times 10^{1}$ \\
\hline Ozone formation (Human) & $\mathrm{OFH}$ & person. ppm. $\mathrm{h}$ & $2.14 \times 10^{-3}$ & $1.78 \times 10^{-3}$ & $4.49 \times 10^{-5}$ & $9.62 \times 10^{-6}$ & $3.98 \times 10^{-3}$ \\
\hline Acidification & $\mathrm{AC}$ & $\mathrm{m}^{2}$ & $5.81 \times 10^{-1}$ & $4.39 \times 10^{0}$ & $3.21 \times 10^{-4}$ & $6.83 \times 10^{-5}$ & $4.97 \times 10^{0}$ \\
\hline Terrestrial eutrophication & $\mathrm{TE}$ & $\mathrm{m}^{2}$ & $3.91 \times 10^{-1}$ & $3.18 \times 10^{-1}$ & $2.16 \times 10^{-4}$ & $4.54 \times 10^{-5}$ & $7.09 \times 10^{-1}$ \\
\hline Aquatic eutrophication EP(N) & AEN & $\operatorname{kg~N}$ & $4.60 \times 10^{-3}$ & $2.84 \times 10^{-3}$ & $3.01 \times 10^{-5}$ & $6.44 \times 10^{-6}$ & $7.47 \times 10^{-3}$ \\
\hline Aquatic eutrophication $\mathrm{EP}(\mathrm{P})$ & AEP & $\mathrm{kg} \mathrm{P}$ & $1.48 \times 10^{-2}$ & $3.07 \times 10^{-3}$ & $9.71 \times 10^{-7}$ & $2.08 \times 10^{-7}$ & $1.78 \times 10^{-2}$ \\
\hline Human toxicity air & HTA & person & $4.29 \times 10^{5}$ & $3.35 \times 10^{5}$ & $6.53 \times 10^{3}$ & $1.40 \times 10^{3}$ & $7.71 \times 10^{5}$ \\
\hline Human toxicity water & HTW & $\mathrm{m}^{3}$ & $2.65 \times 10^{3}$ & $5.33 \times 10^{2}$ & $2.56 \times 10^{1}$ & $5.49 \times 10^{0}$ & $3.21 \times 10^{3}$ \\
\hline Human toxicity soil & HTS & $\mathrm{m}^{3}$ & $1.62 \times 10^{0}$ & $1.21 \times 10^{0}$ & $8.48 \times 10^{-3}$ & $1.82 \times 10^{-3}$ & $2.85 \times 10^{0}$ \\
\hline Ecotoxicity water chronic & EWC & $\mathrm{m}^{3}$ & $8.74 \times 10^{4}$ & $2.13 \times 10^{4}$ & $1.33 \times 10^{3}$ & $2.85 \times 10^{2}$ & $1.10 \times 10^{5}$ \\
\hline Ecotoxicity water acute & EWA & $\mathrm{m}^{3}$ & $1.02 \times 10^{4}$ & $2.67 \times 10^{3}$ & $1.97 \times 10^{2}$ & $4.22 \times 10^{1}$ & $1.31 \times 10^{4}$ \\
\hline Ecotoxicity soil chronic & ESC & $\mathrm{m}^{3}$ & $9.98 \times 10^{0}$ & $8.87 \times 10^{0}$ & $2.45 \times 10^{-3}$ & $5.18 \times 10^{-4}$ & $1.89 \times 10^{1}$ \\
\hline Hazardous waste & HW & $\mathrm{kg}$ & $7.01 \times 10^{-3}$ & $5.47 \times 10^{-5}$ & $7.18 \times 10^{-8}$ & $1.53 \times 10^{-8}$ & $7.06 \times 10^{-3}$ \\
\hline Slags/ashes & $\mathrm{SL}$ & $\mathrm{kg}$ & $5.32 \times 10^{-2}$ & $3.99 \times 10^{-2}$ & $6.73 \times 10^{-5}$ & $1.44 \times 10^{-5}$ & $9.32 \times 10^{-2}$ \\
\hline Bulk waste & BW & $\mathrm{kg}$ & $3.24 \times 10^{-1}$ & $1.22 \times 10^{0}$ & $7.41 \times 10^{-2}$ & $1.50 \times 10^{-2}$ & $1.63 \times 10^{0}$ \\
\hline Radioactive waste & RW & $\mathrm{kg}$ & $1.66 \times 10^{-4}$ & $1.44 \times 10^{-4}$ & $1.40 \times 10^{-7}$ & $2.92 \times 10^{-8}$ & $3.10 \times 10^{-4}$ \\
\hline
\end{tabular}




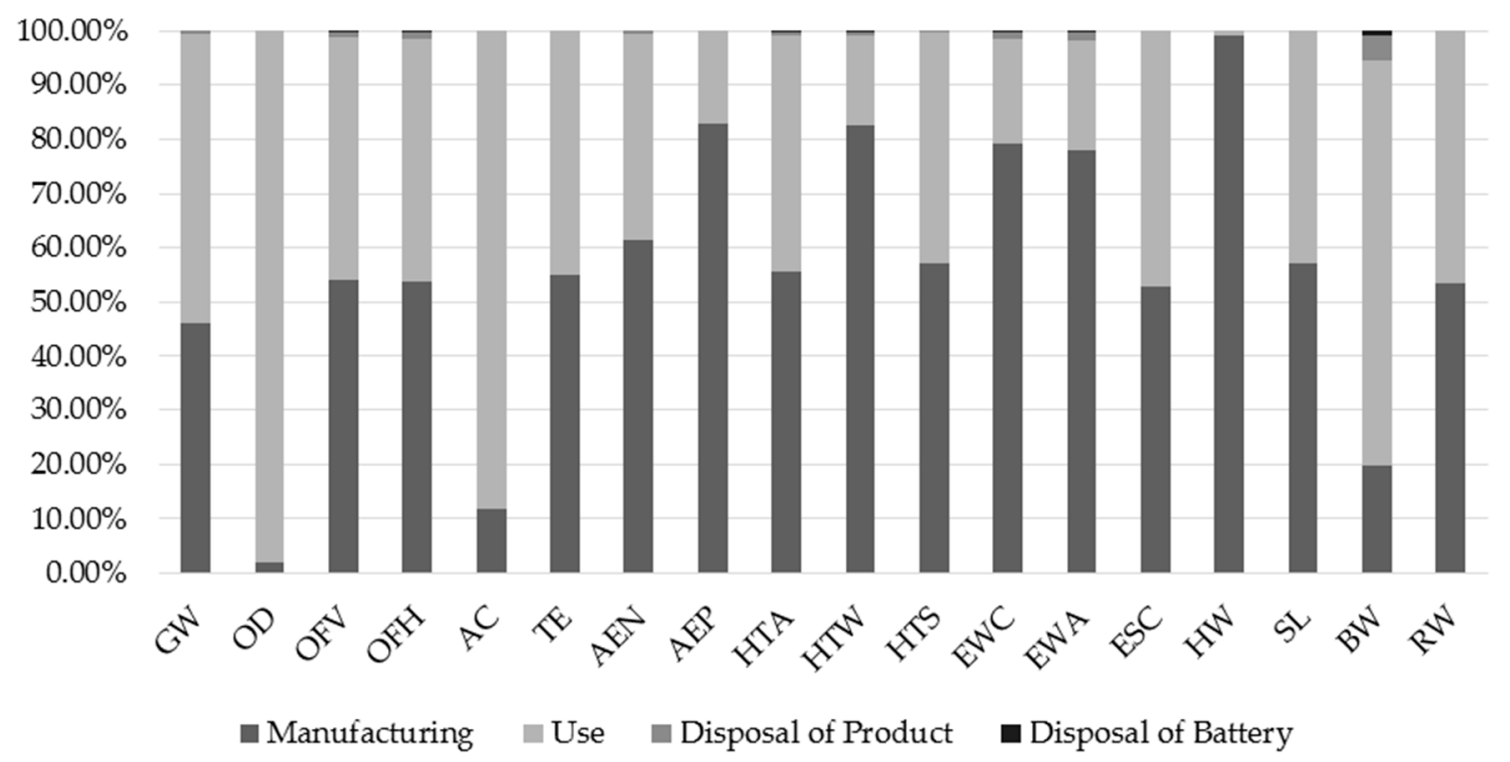

Figure 7. Normalised potential impacts of WLA per life cycle stage.

Table 8. Environmental profile per life cycle stage.

\begin{tabular}{cc}
\hline Stage & Contribution \\
\hline Manufacturing & $75.35 \%$ \\
Use & $23.88 \%$ \\
Disposal of WLA & $0.64 \%$ \\
Disposal of battery & $0.14 \%$ \\
\hline
\end{tabular}

\subsection{Life Cycle Interpretation}

The life cycle interpretation phase consists of three main steps: the identification of hotspots, the evaluation of hotspots, and the conclusions and recommendations. In this sub-section, the critical points of the WLA life cycle would be identified and evaluated. Also, the conclusion of the LCA was summarised at the end of this section. The discussion section was presented in Section 6 to gain a deeper understanding of each environmental impact and to propose a possible recommendation or comparison.

According to Figure 7, there were 14 impact categories that were dominated by the manufacturing stage, while the remaining categories were dominated by the use stage. It can also be seen from Figure 6 that the contributions of the manufacturing stage ranged from $2.02 \%$ for OD to $99.22 \%$ for $\mathrm{HW}$, whereas the contributions of the use stage ranged from $0.77 \%$ for HW to $97.97 \%$ for OD. Moreover, the contributions of the disposal of the WLA ranged from $0.001 \%$ for $\mathrm{HW}$ to $4.53 \%$ for $\mathrm{BW}$, and also the contributions of the battery disposal ranged from $0.0002 \%$ for HW to $0.92 \%$ for BW. Based on Table 7 , it can be concluded that the manufacturing stage of the WLA made the highest contribution of $75.35 \%$ to the environmental impacts. Next, the use stage of the WLA contributed as much as $23.88 \%$ to the environmental impacts. On the other hand, the contributions of the WLA and battery disposal were less significant than the others. The contribution of the WLA disposal was as much as $0.64 \%$, followed by the contribution of the battery disposal of $0.14 \%$.

In the manufacturing stage, the potential impacts which contributed more than $50 \%$ were the OFV (54.13\%), OFH (53.81\%), TE (55.06\%), AEN (61.56\%), AEP (82.79\%), HTA (55.56\%), HTW (82.44\%), HTS $(57.04 \% \%)$, EWC $(79.22 \%)$, EWA $(77.90 \%)$, ESC $(52.94 \%)$, HW (99.22\%), SL $(57.11 \%)$, and RW $(53.48 \%)$. As shown in Figure 8, the contribution analysis indicated that the electronic components have the highest environmental impacts, especially for the Printed Circuit Board (PCB). Approximately $100 \%$ of the hazardous waste impacts occurred at this stage because of the PCB. 


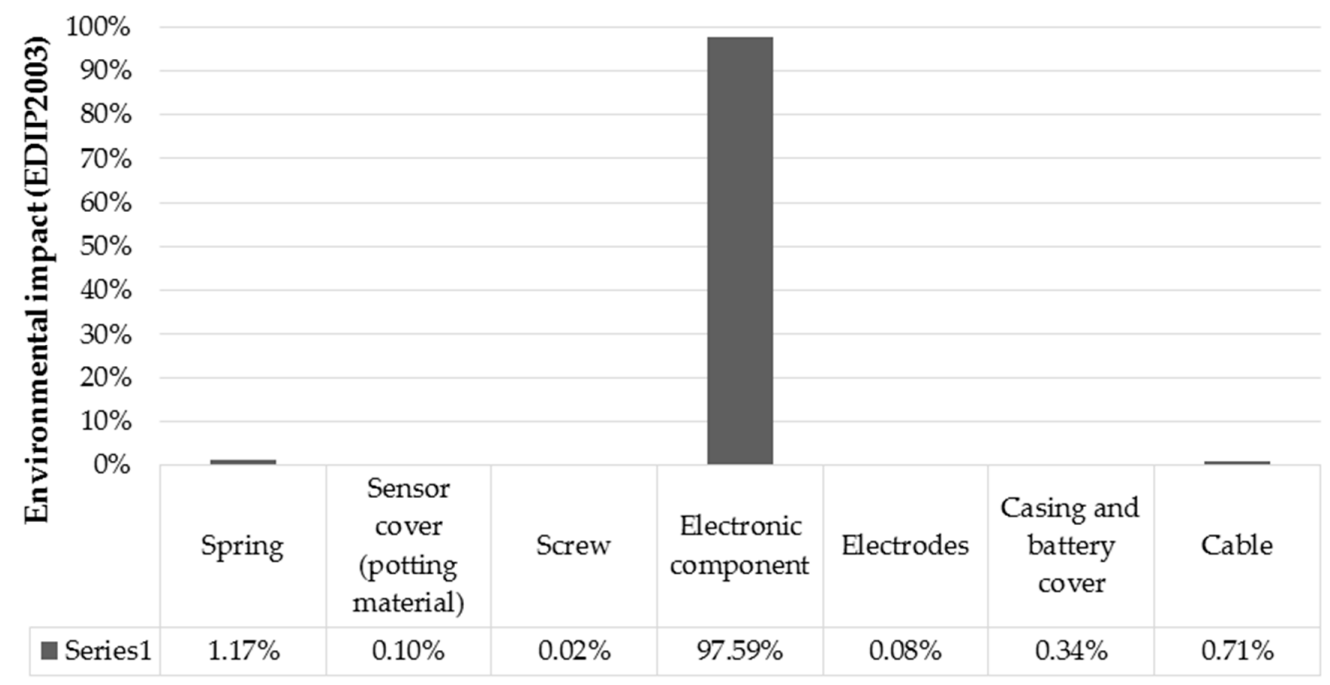

Figure 8. The environmental impact of each electronic component.

Although almost all the impact categories were dominated by the manufacturing stage, there were still many categories that occurred at the use stage. The potential impacts, which contributed more than $40 \%$ at this stage, were detailed as follows: GW $(53.48 \%)$, OD $(97.97 \%)$, OFV $(44.66 \%)$, OFH $(44.82 \%)$, AC $(88.31 \%)$, TE $(44.90 \%)$, HTA $(43.41 \%)$, HTS $(42.60 \%)$, ESC $(47.04 \%)$, SL $(42.80 \%)$, BW $(74.72 \%)$, and RE $(46.47 \%)$. The contribution analysis indicated that the use of nickel metal hydride $(\mathrm{NiMH})$ as rechargeable batteries is not always advantageous. These batteries have a high impact on ozone depletion, eco-toxicity, and acidification. For ozone depletion, the impact of the rechargeable batteries is mostly related to the production of polytetrafluoroethylene (PTFE) at the anode [52].

Lastly, the disposal of the WLA and batteries had a very low impact on the environment. $4.53 \%$ of the bulk waste impact occurred at the product disposal stage because this product was disposed of at a landfill without any further treatment. Nevertheless, it was not comparable to the magnitude of the impacts generated by the manufacturing of PCB. Furthermore, the low impact of the battery disposal was due to the extension of the use stage. Therefore, only $0.92 \%$ of the bulk waste impact was generated during the disposal of the batteries. This revealed that the number of rechargeable batteries used plays an important role in their overall environmental performances [52].

The final task was to draw conclusions and make recommendations. Based on the identification and evaluation of the LCIA results, the following could be inferred:

(1) The stages which contributed to the highest environmental impact were the manufacturing stage, followed by the use stage, the disposal of the WLA, and finally, the disposal of the batteries;

(2) Each stage had different relevant impact categories. For the manufacturing stage, the most interrelated categories were the hazardous waste and aquatic eutrophication categories, whereas the use stage was the main contributor to the ozone depletion and acidification. Moreover, the disposal of the WLA and batteries contributed to the bulk waste.

\section{Results of Design Efficiency Evaluation}

Design efficiency is an important aspect of a product in relation to design parameters [53]. In the previous section, the life cycle aspect of the product was mainly discussed. Since the LCA process only captures the life cycle aspect, the improvement recommendations are still based on environmental concerns. Therefore, in this section, the design efficiency was evaluated to obtain more comprehensive improvements.

The major aim of design efficiency is to decrease the cost and lead time of a product, as well as to maintain its quality [54]. The DFA by Boothroyd et al. [20] was selected to ensure the consistency 
and completeness of the product assemblability evaluation. Usually, a product that is designed to be easily assembled can also be easily disassembled [39]. When a product is easy to disassemble, the opportunity of the product to be recycled or reused will also increase. Even though the DFA is mainly focused on time and cost, this design tool indirectly makes a positive contribution to the environment. This is also supported by the principles of the DFA, such as to minimise the use of unnecessary parts and to reduce the use of fasteners, thereby leading to the reduced consumption of resources. As shown in Figure 9, there are four steps to conducting a design efficiency evaluation. For the first step, as described in Section 4.2, all the product information is collected. Then, a worksheet for calculating the design efficiency was prepared, as shown in Table 9. The detailed calculation of design efficiency evaluation can be seen in Appendixs A-C. The next step is to analyse the ease of assembly, and finally, to improve the design efficiency based on the DFA principles. By implementing the steps of DFA evaluation, the design efficiency of the existing product was found to be $14 \%$.

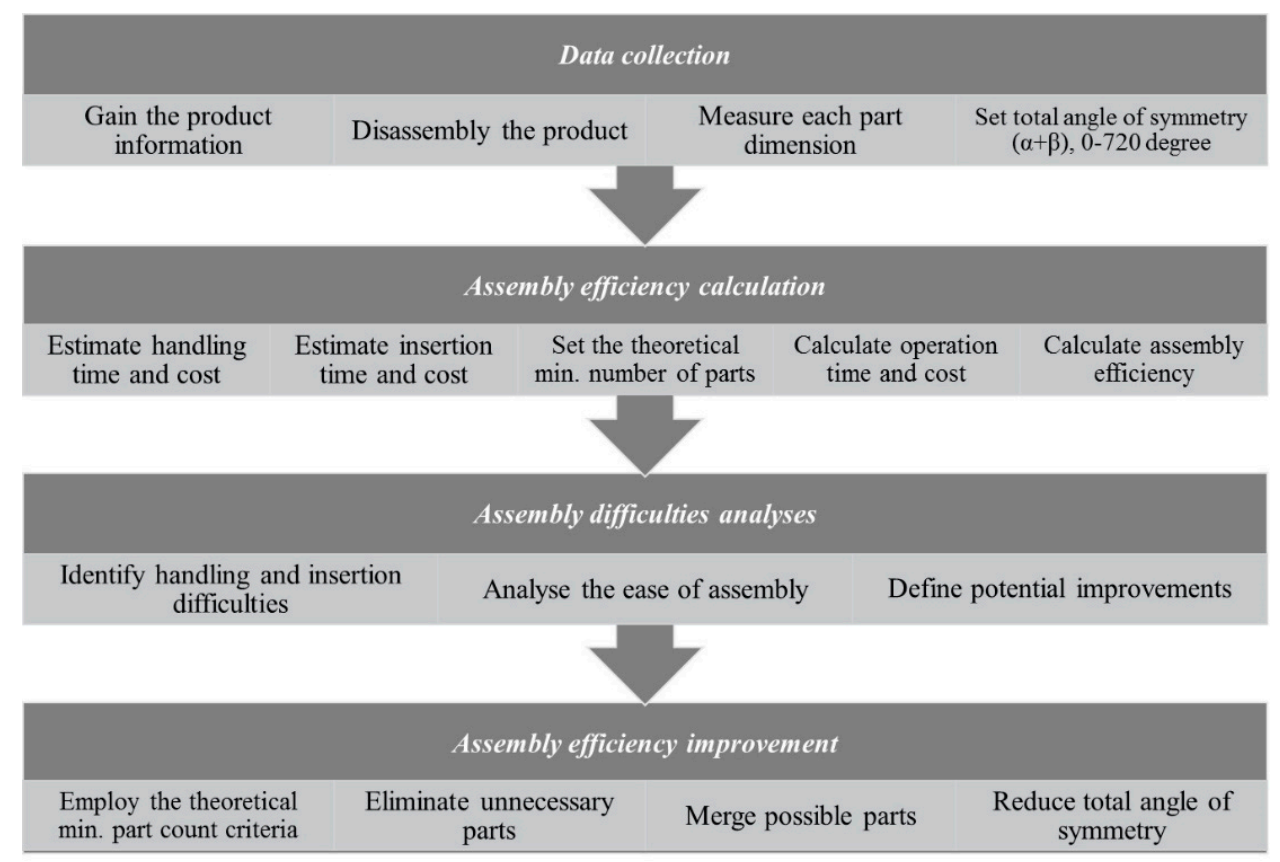

Figure 9. Steps of Design Efficiency Evaluation based on Design for Assembly Principles (adapted from Boothroyd et al. [20]).

Table 9. Design Efficiency Evaluation of Existing Product.

\begin{tabular}{|c|c|c|c|c|c|c|c|c|c|}
\hline Assembly Part & A & B & $\mathrm{C}$ & $\mathbf{D}$ & $\mathbf{E}$ & $\mathbf{F}$ & G & $\mathbf{H}$ & I \\
\hline Front casing & 720 & 1 & 30 & 1.95 & 6 & 5.5 & 7.45 & 2.98 & 1 \\
\hline PCB and electronic components & 720 & 1 & 72 & 5.85 & 96 & 8 & 13.85 & 5.54 & 1 \\
\hline Back casing & 720 & 1 & 30 & 1.95 & 30 & 3.5 & 5.45 & 2.18 & 1 \\
\hline Screw & 360 & 3 & 14 & 2.55 & 59 & 12 & 43.65 & 17.46 & 0 \\
\hline Battery cover & 720 & 1 & 30 & 1.95 & 00 & 1.5 & 3.45 & 1.38 & 1 \\
\hline \multicolumn{7}{|c|}{ Separate calculation table } & 34.16 & 13.66 & 1 \\
\hline \multicolumn{7}{|c|}{ Design efficiency $(3 \times \mathrm{NM} / \mathrm{TM})$} & 108.01 & 43.21 & 5 \\
\hline \multicolumn{7}{|c|}{0.14} & TM & $\mathrm{CM}$ & NM \\
\hline
\end{tabular}

Note: (A) Total angle of symmetry $(\alpha+\beta)$, degree; (B) Number of times the operation is carried out consecutively; (C) Two-digit manual handling code; (D) Manual handling time per part; (E) Two-digit manual insertion code; (F) Manual insertion time per part; (G) Operation time, seconds; (H) Operation costs, cents; (I) Figures for estimation for theoretical minimum parts; (TM) Total operation time, seconds; (CM) Total operation cost, cents; (NM) Total number of parts. 


\section{Discussion}

The product design of WLA has been evaluated based on two perspectives, namely the environmental and design perspectives. In this section, the results from LCA and design evaluation are analysed and discussed in detail. To gain a better understanding on the integration of LCA and DFA, this section is divided into three sub-sections: analysis of the LCA results, analysis of the design evaluation results, and quantitative comparison between the existing and new design.

\subsection{Analysis of the LCA Results}

As explained in the previous section, the PCB production contributed to the highest environmental impact among the other components. During the PCB production, the generated hazardous waste consisted of industrial wastewater and treatment residue, spent process baths, acids used for cleaning the equipment, and copper sulphate crystals [55]. The treatment of wastewater is the main source of hazardous waste in PCB manufacturing because of the copper content in the sludge [56,57]. Moreover, the spent process baths may include cyanides, heavy metals (copper, tin, iron, nickel, and lead), solvents, and other toxic elements in high concentrations. Although the PCB in this study had a lead-free element, the results still showed that it had a great impact on the environment. Furthermore, the cleaning of the electroplating racks could have led to the generation of nitric acid waste with a high copper content. Lastly, the process baths may have generated copper sulphate crystals with increasing copper concentrations. Subsequently, the second highest impact at this stage was aquatic eutrophication. The manufacturing of PCB has a strong influence on the environment, especially on aquatic ecosystems. Thus, it can be poisonous to fishes, even at very low levels [58].

Furthermore, regarding the use of rechargeable batteries, Dolci et al. [52] stated that the inefficient use of these devices (for only 20 charge cycles or less) may have a higher impact than the use of disposable batteries. Therefore, the high impact caused by the production and disposal of rechargeable batteries can be offset by prolonging the use phase. Consumers should use these batteries to their full potential or at least 50 times to minimise the environmental impacts [52].

From the results of the rechargeable batteries used in this study, the disposal stage of the batteries contributed slightly to the environmental impacts. Consumers do not need to purchase many new batteries, which can lead to an abundant waste of batteries. However, since nickel and the electrolyte in the NiMH batteries are semi-toxic, the bulk waste of the NiMH batteries can be dangerous to the health of humans and animals, as well as contaminate air and water in large quantities [59]. Therefore, the recycling of the NiMH batteries is highly recommended to save valuable metals from spent $\mathrm{NiMH}$ batteries and to reduce the generation of waste [60].

Lastly, the disposal of the WLA also made a low contribution to the environmental impacts. When compared to the PCB manufacturing, the bulk waste of the WLA was less significant. However, since some parts of the WLA contain synthetic, metal, and chemical elements, they may be harmful to the environment. Several actions can be implemented to overcome this problem. For synthetic elements like polybutadiene and ABS, the recycling method seems a preferable choice in terms of the environmental and economic benefits. The other recommendation for this case is to replace the synthetic rubber with natural rubber. Clark [61] stated that natural rubber can be disposed of by either landfills or incineration without any environmental damage. This type of rubber is also considered to be an environmentally-degradable material. Furthermore, for metal elements (i.e., copper, stainless steel, and brass), the most appropriate method today is also recycling. Metal recycling helps to preserve valuable natural resources, minimise energy consumption, and decrease production costs [62]. However, this option is still debatable. The recycled metal may contain impurities. The release of toxic emissions may harm workers. Subsequently, this method needs to be examined in-depth and in detail based on a specific problem. Considering this, a triple bottom line of sustainability (environment, economic, and social) should be a wise choice in the decision-making process. 


\subsection{Analysis of the Design Evaluation Results}

From the DFA evaluation, it was found that the design efficiency is $14 \%$. The highest operation time occurred during the insertion of screws and the installation of electronic components. This is because the WLA required three screws to attach and cover the electronic components. Furthermore, the electronic components need more time to be inserted into the inside of the product casing.

To redesign the product, several principles of the DFA that can be employed are minimising the use of fasteners, minimising the number of fastener types, minimising unnecessary parts by combining multiple functions into single parts, and maximising the accessibility of components [39]. Based on these principles, the following design improvements are recommended (see Table 10):

(1) To reduce the number of screws from three units to one unit.

(2) Theoretically, the use of screws in a product should be as minimal as possible. To implement this recommendation, PCB adjustment should be made to fill the space at the front casing component. The PCB should have a hole in the middle so that the screw can lock the back casing in the middle position.

(3) To eliminate the use of a cable and to replace it with a wireless component.

Table 10. Design Efficiency Evaluation of Redesigned Product.

\begin{tabular}{|c|c|c|c|c|c|c|c|c|c|}
\hline Assembly part & A & B & $\mathrm{C}$ & D & $\mathrm{E}$ & $\mathbf{F}$ & G & $\mathbf{H}$ & I \\
\hline Front casing & 720 & 1 & 30 & 1.95 & 6 & 5.5 & 7.45 & 2.98 & 1 \\
\hline Wireless components & 720 & 1 & 72 & 5.85 & 96 & 8 & 13.85 & 5.54 & 1 \\
\hline Back casing & 720 & 1 & 30 & 1.95 & 30 & 3.5 & 5.45 & 2.18 & 1 \\
\hline Screw & 360 & 1 & 14 & 2.55 & 59 & 12 & 14.55 & 5.82 & 0 \\
\hline Battery cover & 720 & 1 & 30 & 1.95 & 00 & 1.5 & 3.45 & 1.38 & 1 \\
\hline \multirow{2}{*}{\multicolumn{7}{|c|}{$\begin{array}{l}\text { Separate calculation table } \\
\text { Design efficiency }(3 \times \mathrm{NM} / \mathrm{TM})\end{array}$}} & 0 & 0 & 1 \\
\hline & & & & & & & 44.75 & 17.90 & 5 \\
\hline \multicolumn{7}{|c|}{0.34} & $\mathrm{TM}$ & $\mathrm{CM}$ & NM \\
\hline
\end{tabular}

Note: (A) Total angle of symmetry $(\alpha+\beta)$, degree; (B) Number of times the operation is carried out consecutively; (C) Two-digit manual handling code; (D) Manual handling time per part; (E) Two-digit manual insertion code; (F) Manual insertion time per part; (G) Operation time, seconds; (H) Operation costs, cents; (I) Figures for estimation for theoretical minimum parts; (TM) Total operation time, seconds; (CM) Total operation cost, cents; (NM) Total number of parts.

Thirty-two-percent of the assembly time was taken up with the installation of the cable. Therefore, the proposed improvement to reduce the operation time was to eliminate the use of the cable and to replace it with a wireless component (see Table 10). The wireless system is now considered as a green technology. This system promises some benefits, such as easier installation and less consumption of materials. However, the use of a wireless component may incur a higher cost. The trade-off between environmental and economic objectives requires a deeper study to make the best decision. However, from the redesign evaluation, implementing the two proposed recommendations can increase the design efficiency from $14 \%$ to $34 \%$.

\subsection{Quantitative Comparison between the Existing and New Design}

An LCA study has been conducted to compare the environmental impacts between the existing product (wired alarm) and the redesigned product (wireless alarm). As discussed in Section 5, the wireless alarm consists of front casing, back casing, screw, siren, electrodes, spring, switch button, and wireless components. There are several types of wireless technology, such as Wi-Fi, Bluetooth, and low-cost spread-spectrum radios (802.15.4). In this study, Wi-Fi was used as the chosen technology because it has a high data rate and simple configuration [63]. During the use stage, the wireless alarm requires rechargeable $9 \mathrm{~V} \mathrm{Ni}-\mathrm{MH}$ batteries. In order to be used for a duration of 3 years, the alarm requires 1 battery which will be recharged every year and the electricity for charging the battery was 
as much as $41.96 \mathrm{~W} \mathrm{~h}$. As shown in Table 11, this assumption was based on the energy requirement for 3 years which was equivalently determined to the required energy for the wired alarm. As in the case of the existing product, the redesigned product was also assumed to be disposed of in landfills after the use stage.

Table 11. Comparison of battery usage between a wired alarm and wireless alarm.

\begin{tabular}{ccc}
\hline Type of Alarm & Wired Alarm & Wireless Alarm \\
\hline Type of battery & Rechargeable AAA battery & Rechargeable 9 V battery \\
Chemical system & Nickel metal hydride (Ni-MH) & Nickel metal hydride (Ni-MH) \\
Nominal voltage & $1.5 \mathrm{~V}$ & $9 \mathrm{~V}$ \\
Capacity & 2 watt hour & 5.49 watt hour \\
Weight & $\pm 15 \mathrm{~g}$ & $\pm 45 \mathrm{~g}$ \\
Total electricity for recharging & 115.2 watt hour & 41.96 watt hour \\
\hline
\end{tabular}

As shown in Figure 10, the manufacturing of a wireless alarm has a higher environmental impact compared to the wired alarm. This is due to the production of wireless components that may impart an adverse impact to the environment (see Figure 11). However, during the use stage, the wireless alarm is more energy efficient and has less impact on the environment because it requires less electricity for recharging the batteries. The disposal of the wireless alarm also has a lower impact because the redesigned product uses less materials than the existing one. However, the impact from battery disposal was higher than the wired alarm. Overall, there is not much difference between the wired alarm and wireless alarm from the environmental perspective.

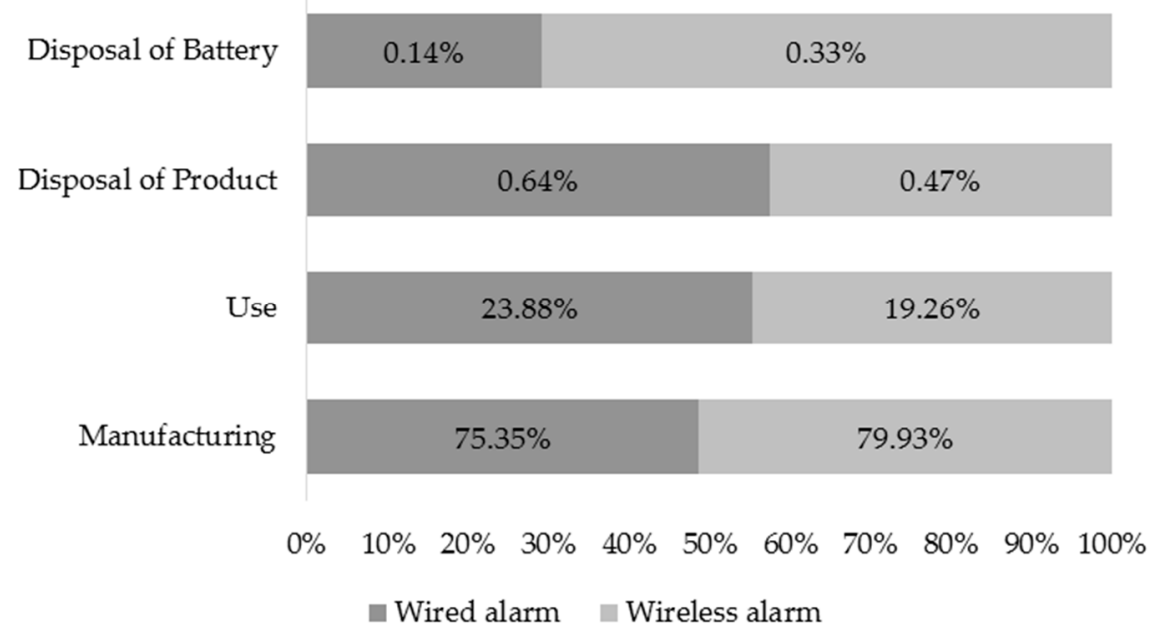

Figure 10. A comparison of environmental impacts between the wired alarm and the wireless alarm. 


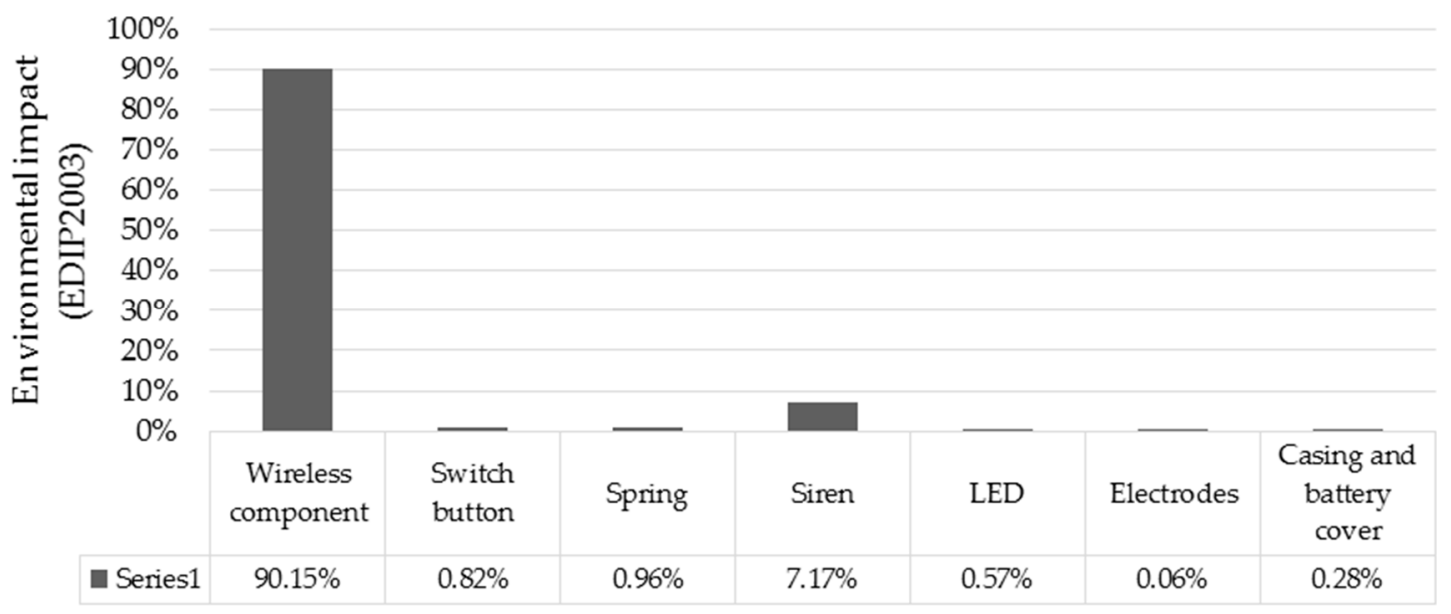

Figure 11. The environmental impacts of each wireless alarm part.

The environmental impacts of the design improvements could be seen from the reduction of material consumption. This reduction would minimise the environmental burden of the product in the long term. Furthermore, any reduction in the number of parts in an assembly generates a snowball effect on cost reduction [20]. It can be seen in Tables 8 and 9 that the assembly cost was reduced from 43.21 cents to 17.90 cents. Moreover, the savings in material costs could also be increased as a result of the parts simplification.

\section{Conclusions}

To answer the objective of this study, an LCA was performed on a water leakage alarm. It was found that 14 impact categories were dominated by the manufacturing stage, whereas the remaining categories were dominated by the use stage. On the other hand, the contributions of the WLA and battery disposal were less significant than the other categories.

Furthermore, since the purpose of this study was to integrate the LCA and DFA method, the next step was to evaluate the design efficiency of the product using the DFA guidelines. From the evaluation, the design efficiency of the existing product was found to be $14 \%$. The two proposed improvements for redesigning the WLA were as follows: (1) To reduce the number of screws from three units to one unit, and (2) to eliminate the use of a cable and to replace it with a wireless component. The implementation of the two recommendations has improved the design efficiency by as much as $34 \%$.

From the environmental perspective, there is not much difference between the wired alarm and wireless alarm. The wired alarm has a lower environmental impact during its manufacturing stage, however, the environmental impact is higher during its use stage. Contrarily, the production of wireless components results in higher environmental impacts than the production of general electronic components. This could be due to the complexity and limited knowledge on the production of new technology components leading to a more negative impact to the environment. However, based on the study, it was found that during the use stage, the wireless alarm requires less energy compared to the wired alarm. Generally, it can be concluded that the wired alarm has advantages in terms of the environmental impacts while the wireless alarm is superior in terms of design for assembly.

This paper contributes to the knowledge from the outlined literature review by providing insights into the development of the product design by using a life cycle technique. Moreover, this paper practically contributes towards the evaluation of environmental impacts and assembly time of the product. The combination of LCA and design evaluation provides a comprehensive perspective of the product life cycle. For further researches, more LCA studies focusing on detailed problems are required, such as PCB manufacturing, rubber recycling, and metal recycling. Also, a study on the 
trade-offs between the environmental and economic aspects of a wireless system could provide some useful findings for the product sustainability.

Author Contributions: Conceptualization, T.T.S. and D.A.W.; Formal analysis, T.T.S.; Investigation, T.T.S.; Methodology, T.T.S.; Software, T.T.S.; Supervision, D.A.W. and M.N.A.R.; Writing-Original draft, T.T.S.; Writing-Review \& editing, D.A.W.

Funding: This research is partly funded by Universiti Kebangsaan Malaysia under research grant AP-2015-008.

Acknowledgments: The authors would like to acknowledge the support of Universiti Kebangsaan Malaysia (UKM) under research grant AP-2015-008 and The Ministry of Higher Education, Malaysia for the Malaysia International Scholarship (MIS) of the researcher.

Conflicts of Interest: The authors declare no conflict of interest. The funders had no role in the design of the study; in the collection, analyses, or interpretation of data; in the writing of the manuscript, and in the decision to publish the results.

\section{Appendix A}

Table A1. Two-digit manual handling code (existing design).

\begin{tabular}{|c|c|c|c|c|c|c|}
\hline \multirow{2}{*}{ Assembly Part } & \multirow{2}{*}{$(\alpha+\beta)$} & \multirow{2}{*}{ First Digit } & \multicolumn{2}{|c|}{ Handling Difficulties } & \multirow{2}{*}{$\begin{array}{l}\text { Second } \\
\text { Digit }\end{array}$} & \multirow{2}{*}{$\begin{array}{l}\text { Handling } \\
\text { Time }\end{array}$} \\
\hline & & & Easy Grasps & Thickness & & \\
\hline Front casing & $\alpha=360 \beta=360$ & 3 & Yes & $2 \mathrm{~mm}$ & 0 & 1.95 \\
\hline PCB & $\alpha=360 \beta=360$ & 7 & \multicolumn{2}{|c|}{$\begin{array}{l}\text { Can be manipulated without } \\
\text { optical magnification; present } \\
\text { handling difficulties }\end{array}$} & 2 & 5.85 \\
\hline Back casing & $\alpha=360 \beta=360$ & 3 & Yes & $2 \mathrm{~mm}$ & 0 & 1.95 \\
\hline Screw & $\alpha=360 \beta=0$ & 1 & Yes & $1.85 \mathrm{~mm}$ & 4 & 2.55 \\
\hline Battery cover & $\alpha=360 \beta=360$ & 3 & Yes & $2 \mathrm{~mm}$ & 0 & 1.95 \\
\hline
\end{tabular}

\section{Appendix B}

Table A2. Two-digit manual insertion code (existing design) for part added but not secured.

\begin{tabular}{|c|c|c|c|c|c|c|c|}
\hline \multicolumn{8}{|c|}{ Part Added but Not Secured } \\
\hline \multirow{2}{*}{$\begin{array}{l}\text { Assembly } \\
\text { Part }\end{array}$} & \multicolumn{2}{|c|}{ Access Vision } & \multirow{2}{*}{ 1st Digit } & \multicolumn{2}{|c|}{ Insertion Difficulties } & \multirow{2}{*}{ 2nd Digit } & \multirow{2}{*}{ Ins. Time } \\
\hline & $\begin{array}{l}\text { Obstructed } \\
\text { Vision }\end{array}$ & $\begin{array}{c}\text { Restricted } \\
\text { Vision }\end{array}$ & & $\begin{array}{c}\text { Holding } \\
\text { Down }\end{array}$ & $\begin{array}{l}\text { Easy to } \\
\text { Align }\end{array}$ & & \\
\hline $\begin{array}{l}\text { Front } \\
\text { casing }\end{array}$ & No & No & 0 & Yes & Yes & 6 & 5.5 \\
\hline $\begin{array}{l}\text { Back } \\
\text { casing }\end{array}$ & No & No & 0 & No & Yes & 3 & 3.5 \\
\hline $\begin{array}{l}\text { Battery } \\
\text { cover }\end{array}$ & No & No & 0 & No & Yes & 0 & 1.5 \\
\hline
\end{tabular}

Table A3. Two-digit manual insertion code (existing design) for part secured immediately.

\begin{tabular}{|c|c|c|c|c|c|c|}
\hline \multicolumn{7}{|c|}{ Part Secured Immediately } \\
\hline \multirow{2}{*}{$\begin{array}{c}\text { Assembly } \\
\text { Part }\end{array}$} & \multicolumn{2}{|c|}{ Access Vision } & \multirow{2}{*}{$\begin{array}{c}\text { 1st } \\
\text { Digit }\end{array}$} & & \multirow{2}{*}{$\begin{array}{l}\text { 2nd } \\
\text { Digit }\end{array}$} & \multirow{2}{*}{$\begin{array}{c}\text { Insertion } \\
\text { Time }\end{array}$} \\
\hline & $\begin{array}{l}\text { Obstructed } \\
\text { Vision }\end{array}$ & $\begin{array}{l}\text { Restricted } \\
\text { Vision }\end{array}$ & & & & \\
\hline Screw & Yes & Yes & 5 & $\begin{array}{l}\text { Screw tightening } \\
\text { immediately after insertion; } \\
\text { Not easy to align }\end{array}$ & 9 & 12 \\
\hline
\end{tabular}


Table A4. Two-digit manual insertion code (existing design) for separate operation.

\begin{tabular}{cccccc}
\hline \multicolumn{5}{c}{ Separate Operation } & \\
\hline $\begin{array}{c}\text { Assembly } \\
\text { Operation }\end{array}$ & 1st Digit & 2nd Digit & $\begin{array}{c}\text { Insertion } \\
\text { Time }\end{array}$ \\
\hline Place PCB assembly & $\begin{array}{c}\text { Assembly processes where } \\
\text { all solid parts are in place }\end{array}$ & 9 & $\begin{array}{c}\text { Soldered } \\
\text { process }\end{array}$ & 5 & 8 \\
\hline
\end{tabular}

\section{Appendix C}

Table A5. Cable Installation Operation Time.

\begin{tabular}{cccc}
\hline Assembly Part & Process & Time & Total Time (s) \\
\hline \multirow{4}{*}{ Cable } & Preparation & 8.3 & \\
& Handling & 3.364 & \\
& Insertion & 2.5 & 34.164 \\
& Dressing & 2.3 & \\
& Fastening & 13.5 & \\
& Routing & 4.2 & \\
\hline
\end{tabular}

\section{References}

1. Irhoma, A.; Su, D.; Higginson, M. Analysis and evaluation of the environmental impacts of "upstream" petroleum operations. Int. J. Manuf. Technol. Manag. 2016, 30, 116-142. [CrossRef]

2. Iritani, D.R.; Silva, D.A.L.; Saavedra, Y.M.B.; Grael, P.F.F.; Ometto, A.R. Sustainable strategies analysis through Life Cycle Assessment: A case study in a furniture industry. J. Clean. Prod. 2015, 96, 308-318. [CrossRef]

3. MTS Life Cycle Assessment (LCA) and Sustainable Product Standards Training. Available online: http: / / mts.sustainableproducts.com (accessed on 1 September 2016).

4. Jaafar, I.H.; Venkatachalam, A.; Joshi, K.; Ungureanu, A.C.; De Silve, N.; Rouch, K.E.; Dillon, O.W.; Jawahir, I.S. Product Design for Sustainability: A New Assessment Methodology and Case Studies. In Environmentally Conscious Mechanical Design; Kutz, M., Ed.; John Wiley \& Sons, Inc.: Hoboken, NJ, USA, 2007; pp. $25-62$.

5. Intergovernmental Panel on Climate Change (IPCC). Climate Change 2014: Mitigation of Climate Change Contribution of Working Group III to the Fifth Assessment Report of the Intergovernmental Panel on Climate Change; IPCC: Cambridge, UK; New York, NY, USA, 2014.

6. Baldé, C.P.; Wang, F.; Kuehr, R.; Huisman, J. The Global E-Waste Monitor 2014; United Nations University, IAS—SCYCLE: Bonn, Germany, 2014.

7. UNEP Illegally Traded and Dumped E-Waste Worth Up to $\$ 19$ Billion Annually Poses Risks to Health, Deprives Countries of Resources, Says UNEP Report-UNEP. Available online: http:/ / www.unep.org/ newscentre/default.aspx?DocumentID=26816\&ArticleID=35021 (accessed on 17 March 2016).

8. International Standard Organization (ISO). 14040 Environmental Management-Life Cycle Assessment_-Principles and Framework (ISO 14040:2006), 2nd ed.; International Standard Organization (ISO): Geneva, Switzerland, 2006.

9. Bevilacqua, M.; Ciarapica, F.E.; Giacchetta, G. Design for Environment as a Tool for the Development of a Sustainable Supply Chain; Springer: London, UK, 2012; Volume 53.

10. Compagno, L.; Ingrao, C.; Latora, A.G.; Trapani, N. Life cycle assessment of CRT lead recovery process. Int. J. Prod. Lifecycle Manag. 2014, 7, 201-214. [CrossRef]

11. Koffler, C.; Krinke, S.; Schebek, L.; Buchgeister, J. Volkswagen slimLCI: A procedure for streamlined inventory modelling within life cycle assessment of vehicles. Int. J. Veh. Des. 2008, 46, 172-188. [CrossRef]

12. Meyer, D.E.; Katz, J.P. Analyzing the environmental impacts of laptop enclosures using screening-level life cycle assessment to support sustainable consumer electronics. J. Clean. Prod. 2015, 112, 369-383. [CrossRef]

13. Xiao, R.; Zhang, Y.; Liu, X.; Yuan, Z. A life-cycle assessment of household refrigerators in China. J. Clean. Prod. 2015, 95, 301-310. [CrossRef] 
14. Xie, M.; Bai, W.; Bai, L.; Sun, X.; Lu, Q.; Yan, D.; Qiao, Q. Life cycle assessment of the recycling of Al-PE (a laminated foil made from polyethylene and aluminum foil) composite packaging waste. J. Clean. Prod. 2015, 112, 4430-4434. [CrossRef]

15. Barreto, L.-V.; Anderson, H.; Anglin, A.; Tomovic, C. Product lifecycle management in support of green manufacturing: Addressing the challenges of global climate change. Int. J. Manuf. Technol. Manag. 2010, 19, 294-305. [CrossRef]

16. Wahab, D.A. Designing products in today's global economy: End-of-life issues and challenges. In Proceedings of the International Seminar on Industrial Engineering and Management, Lombok, Indonesia, 1-4 December 2010.

17. Keoleian, G.A. The appliacation of life cycle assessment to design. J. Clean. Prod. 1993, 1, 143-149. [CrossRef]

18. Chang, D.; Lee, C.K.M.; Chen, C.-H. Review of life cycle assessment towards sustainable product development. J. Clean. Prod. 2014, 83, 48-60. [CrossRef]

19. Navajas, A.; Uriarte, L.; Gandía, L.M. Application of eco-design and life cycle assessment standards for environmental impact reduction of an industrial product. Sustainability 2017, 9, 1724. [CrossRef]

20. Boothroyd, G.; Dewhurst, P.; Knight, W.A. Product Design for Manufacture and Assembly, 3rd ed.; CRC Press: Boca Raton, FL, USA, 2011; Volume 1.

21. Fitzpatrick, C.; Hickey, S.; Schischke, K.; Maher, P. Sustainable life cycle engineering of an integrated desktop PC; A small to medium enterprise perspective. J. Clean. Prod. 2014, 74, 155-160. [CrossRef]

22. Jian, X.; Cai, S.; Chen, Q. A study on the evaluation of product maintainability based on the life cycle theory. J. Clean. Prod. 2016, 141, 481-491. [CrossRef]

23. Park, J.-H.; Seo, K.-K. A knowledge-based approximate life cycle assessment system for evaluating environmental impacts of product design alternatives in a collaborative design environment. Adv. Eng. Inform. 2006, 20, 147-154. [CrossRef]

24. Sakao, T. A QFD-centred design methodology for environmentally conscious product design. Int. J. Prod. Res. 2007, 45, 4143-4162. [CrossRef]

25. Umeda, Y.; Fukushige, S.; Tonoike, K.; Kondoh, S. Product modularity for life cycle design. CIRP Ann. Manuf. Technol. 2008, 57, 13-16. [CrossRef]

26. Choi, Y.; Mai, D.Q. The sustainable role of the e-trust in the B2C e-commerce of Vietnam. Sustainability 2018, 10, 291. [CrossRef]

27. Li, L.; Wu, W.; Giller, P.; O’Halloran, J.; Liang, L.; Peng, P.; Zhao, G. Life cycle assessment of a highly diverse vegetable multi-cropping system in Fengqiu County, China. Sustainability 2018, 10, 983. [CrossRef]

28. Lee, K.-H.; Cheong, I.-M. Measuring a carbon footprint and environmental practice: The case of Hyundai Motors Co. (HMC). Ind. Manag. Data Syst. 2011, 111, 961-978. [CrossRef]

29. International Standard Organization (ISO). 14044 Environmental Management-Life Cycle Assessment-Requirement and Guidelines (ISO 14044:2006); ISO: Geneva, Switzerland, 2006.

30. Guinee, J.B.; Gorree, M.; Heijungs, R.; Huppes, G.; Kleijn, R.; de Koning, A.; van Oers, L.; Sleeswijk, A.W.; Suh, S.; de Haes, H.A.U.; et al. Handbook on Life Cycle Assessment-Operational Guide to the ISO Standards; Tukker, A., Ed.; Kluwer Academic Publisher: New York, NY, USA; Boston, MA, USA; Dordrecht, The Netherlands; London, UK; Moscow, Russian, 2002; Volume 7.

31. Peng, W.; Huang, H.-Z.; Li, Y.; Zuo, M.J.; Xie, M. Life cycle reliability assessment of new products-A Bayesian model updating approach. Reliab. Eng. Syst. Saf. 2013, 112, 109-119. [CrossRef]

32. Kim, S.J.; Kara, S.; Kayis, B. Economic and environmental assessment of product life cycle design: Volume and technology perspective. J. Clean. Prod. 2014, 75, 75-85. [CrossRef]

33. Matsuyama, Y.; Fukushige, S.; Umeda, Y. Simulating life cycles of individual products for life cycle design. Procedia CIRP 2015, 38, 159-164. [CrossRef]

34. Lewis, H.; Gertsakis, J.; Grant, T.; Morelli, N.; Sweatman, A. Introduction. In Design + Environment a Global Guide to Designing Greener Goods; Greenleaf Publishing Limited: Sheffield, UK, 2001; pp. 13-30.

35. Kobayashi, H. Strategic evolution of eco-products: A product life cycle planning methodology. Res. Eng. Des. 2005, 16, 1-16. [CrossRef]

36. Martin, M.V.; Ishii, K. Design for variety: Developing standardized and modularized product platform architectures. Res. Eng. Des. 2002, 13, 213-235. [CrossRef]

37. Fitch, P.; Cooper, J.S. Life-cycle modeling for adaptive and variant design. Part 1: Methodology. Res. Eng. Des. 2005, 15, 216-228. [CrossRef] 
38. Go, T.F.; Wahab, D.A.; Hishamuddin, H. Multiple generation life-cycles for product sustainability: The way forward. J. Clean. Prod. 2015, 95, 16-29. [CrossRef]

39. Otto, K.L.; Wood, K.N. Product Design: Techniques in Reverse Engineering and New Product Development; Prentice Hall: Upper Saddle River, NJ, USA, 2001.

40. Kaebernick, H.; Kara, S. Reuse and Recycling Technologies. In Environmentally Conscious Mechanical Design; John Wiley \& Sons, Inc.: Toronto, ON, Canada, 2007; pp. 249-282.

41. Bogue, R. Design for disassembly: A critical twenty-first century discipline. Assem. Autom. 2007, 27, $285-289$. [CrossRef]

42. Bras, B. Design for Remanufacturing Processes. In Environmentally Conscious Mechanical Design; John Wiley \& Sons, Inc.: Toronto, ON, Canada, 2007; pp. 283-318.

43. Go, T.F.; Wahab, D.A.; Rahman, M.N.A.; Ramli, R.; Azhari, C.H. Disassemblability of end-of-life vehicle: A critical review of evaluation methods. J. Clean. Prod. 2011, 19, 1536-1546. [CrossRef]

44. Tchertchian, N.; Liang, H.; Millet, D. The influence of multiple life cycles on the environmental impact of a product. In International Conference on Engineering Design (ICED); Standford University: Stanford, CA, USA, 2009; pp. 185-196.

45. Miranda de Souza, V.; Borsato, M. Combining Stage-Gate ${ }^{\mathrm{TM}}$ model using Set-Based concurrent engineering and sustainable end-of-life principles in a product development assessment tool. J. Clean. Prod. 2016, 112, 3222-3231. [CrossRef]

46. Lacasa, E.; Santolaya, J.L.; Biedermann, A. Obtaining sustainable production from the product design analysis. J. Clean. Prod. 2016, 139, 706-716. [CrossRef]

47. Pré Sustainability SimaPro FAQ: What Is the Difference between Ecoinvent Market and Transformation Processes? Available online: http:/ / support.simapro.com/articles/FAQ/What-is-the-difference-betweenecoinvent-market-and-transformation-processes (accessed on 22 July 2018).

48. Cooper, J.S. Specifying functional units and reference flows for comparable alternatives. Int. J. Life Cycle Assess. 2003, 8, 337-349. [CrossRef]

49. Sikdar, B. A Study of the Environmental Impact of Wired and Wireless Local Area Network Access. IEEE Trans. Consum. Electron. 2013, 59, 85-92. [CrossRef]

50. Pré Sustainability. SimaPro Database Manual Methods Library; Pré Sustainability: Amersfoort, The Netherlands, 2016.

51. Hauschild, M.; Potting, J. Spatial differentiation in life cycle impact assessment-The EDIP2003 methodology. 2005. Available online: https://www.researchgate.net/publication/281573193_Spatial_Differentiation_in_ Life_Cycle_Impact_Assessment_-_The_EDIP_2003_Methodology (accessed on 22 July 2018).

52. Dolci, G.; Tua, C.; Grosso, M.; Rigamonti, L. Life cycle assessment of consumption choices: A comparison between disposable and rechargeable household batteries. Int. J. Life Cycle Assess. 2016, 21, 1691-1705. [CrossRef]

53. Aas, E.J. Design Quality and Design Efficiency: Definitions, Metrics, and Relevant Design Experiences. In IEEE 2000 First International Symposium on Quality Electronic Design; Titsworth, F., Ed.; IEEE Computer Society: San Jose, CA, USA, 2000; pp. 389-394.

54. Chiu, M.C.; Kremer, G.E.O. Investigation of the applicability of Design for $\mathrm{X}$ tools during design concept evolution: A literature review. Int. J. Prod. Dev. 2011, 13, 132. [CrossRef]

55. UDEQ Printed Circuit Board Manufacturers' Fact Sheet. Available online: http://digitallibrary.utah.gov/ awweb / awarchive?type=file\&item $=16566$ (accessed on 12 October 2016).

56. Environmental Protection Agency (EPA). Guides to Pollution Prevention: The Printed Circuit Board Manufacturing Industry; EPA: Cincinati, OH, USA, 1990.

57. International Finance Corporation (IFC). Environmental, Health, and Safety Guidelines for Semiconductors $\mathcal{E}$ Other Electronics Manufacturing; IFC: Hong Kong, China, 2007.

58. EC. The PCB Regulations and Metal Recyclers and Hazardous Waste Service Providers. Available online: http:/ / www.ec.gc.ca/bpc-pcb/default.asp?lang=En\&n=4758DDF5-BAC1-4AAC-8F7B (accessed on 12 October 2016).

59. Bennett, S. How to Recycle NiMH Batteries. Available online: http:/ / recyclenation.com/2015/06/how-torecycle-nimh-batteries (accessed on 13 October 2016). 
60. Tanabe, E.H.; Schlemmer, D.F.; Aguiar, M.L.; Dotto, G.L.; Bertuol, D.A. Recovery of valuable materials from spent NIMH batteries using spouted bed elutriation. J. Environ. Manag. 2016, 171, 177-183. [CrossRef] [PubMed]

61. Clark, T. Advancements in rubber disposal: Biodegradation and the Environment. In Proceedings of the International Latex Conference 2013, Akron, OH, USA, 23-24 July 2013.

62. Leigh, E. Effects of Recycling on Humans. Available online: http:/ / homeguides.sfgate.com/effects-recyclinghumans-79735.html (accessed on 13 October 2016).

63. Roving Networks RN-XV Data Sheet. Available online: http://dlnmh9ip6v2uc.cloudfront.net/datasheets/ Wireless/WiFi/WiFly-RN-XV-DS.pdf (accessed on 22 July 2018).

(C) 2018 by the authors. Licensee MDPI, Basel, Switzerland. This article is an open access article distributed under the terms and conditions of the Creative Commons Attribution (CC BY) license (http://creativecommons.org/licenses/by/4.0/). 